\title{
Review \\ Current Achievements and Applications of Transcriptomics in Personalized Cancer Medicine
}

\author{
Stanislaw Supplitt ${ }^{1, *}$, Pawel Karpinski ${ }^{1,2}{ }^{\mathbb{O}}$, Maria Sasiadek ${ }^{1}$ and Izabela Laczmanska ${ }^{1}$ \\ 1 Department of Genetics, Wroclaw Medical University, Marcinkowskiego 1, 50-368 Wroclaw, Poland; \\ polemiraza@poczta.fm (P.K.); maria.sasiadek@umed.wroc.pl (M.S.); izabela.laczmanska@umed.wroc.pl (I.L.) \\ 2 Laboratory of Genomics and Bioinformatics, Hirszfeld Institute of Immunology and Experimental Therapy, \\ Polish Academy of Sciences, Weigla 12, 53-114 Wroclaw, Poland \\ * Correspondence: st.supplitt@gmail.com; Tel.: +48-71-784-1258
}

\section{check for}

updates

Citation: Supplitt, S.; Karpinski, P.; Sasiadek, M.; Laczmanska, I. Current Achievements and Applications of Transcriptomics in Personalized Cancer Medicine. Int. J. Mol. Sci. 2021, 22, 1422. https://doi.org/10.3390/ ijms22031422

Received: 20 November 2020

Accepted: 21 January 2021

Published: 31 January 2021

Publisher's Note: MDPI stays neutral with regard to jurisdictional claims in published maps and institutional affiliations.

Copyright: (c) 2021 by the authors. Licensee MDPI, Basel, Switzerland. This article is an open access article distributed under the terms and conditions of the Creative Commons Attribution (CC BY) license (https:// creativecommons.org/licenses/by/ $4.0 /)$.

\begin{abstract}
Over the last decades, transcriptome profiling emerged as one of the most powerful approaches in oncology, providing prognostic and predictive utility for cancer management. The development of novel technologies, such as revolutionary next-generation sequencing, enables the identification of cancer biomarkers, gene signatures, and their aberrant expression affecting oncogenesis, as well as the discovery of molecular targets for anticancer therapies. Transcriptomics contribute to a change in the holistic understanding of cancer, from histopathological and organic to molecular classifications, opening a more personalized perspective for tumor diagnostics and therapy. The further advancement on transcriptome profiling may allow standardization and cost reduction of its analysis, which will be the next step for transcriptomics to become a canon of contemporary cancer medicine.
\end{abstract}

Keywords: transcriptomics; RNA; cancer; oncogenesis; personalized medicine

\section{Introduction}

Cancers are a highly heterogeneous group of diseases whose sensitivity to the therapy varies considerably among patients [1]. The commonly accepted clinical principle attributes the histological type of tumor and its stage, according to the tumor-node-metastasis (TNM) system, as the causes of differences in the treatment response [2,3]. However, the understanding of cancer biology has changed significantly over the last years due to the prominent progress in genomics. Since the completion of the Human Genome Project and development of next generation sequencing (NGS) techniques, the structure and functions of the genome, as well as mechanisms regulating genes' expression have been extensively explored in the context of oncology [4,5]. The constantly widening knowledge on genomic background of malignant transformation brings a new insight into the molecular justification of pathogenesis of particular tumors and their targeted treatment [6,7].

The branch of molecular genetics with remarkably fast-paced development over the recent years is transcriptomics $[4,8]$. A transcriptome is a set of all the RNA molecules transcribed from the genome in a given cell, at a particular developmental stage and under certain physiological or pathological conditions $[9,10]$. It includes protein-coding RNAs (pcRNAs), typically referred to as messenger RNAs (mRNAs), and non-coding RNAs (ncRNAs), from which every particular molecule presents different spectrum of functions in the cell and reacts variously to environmental stimuli [11-14]. The transcriptome profile can be regarded as a snapshot of the temporary cell state and thus, its analysis provides not only information on gene function, but also reveals details on the genome plasticity, gene expression regulation, and modifications of individual transcripts [15]. Therefore, transcriptome analysis is considered as a useful approach for investigation of constantly changing cancer cells at a molecular level. Obtained conclusions contribute directly to the intensive development of precision oncology [16-18]. 
The article summarizes the current achievements of transcriptomics in oncology with an emphasis on its potential in guiding diagnostics and anticancer therapies.

\section{Omics: Different Levels of Gene Expression}

The knowledge on the genetic principles of neoplastic transformation enables its application both for molecular and clinical purposes [19]. The development of cancer is always associated with genetic and epigenetic changes accumulated within the cell, through which it acquires aberrant biological features specific for cancer cells (e.g., loss of apoptosis, insensitivity to regulatory factors, uncontrolled growth and cell division) $[20,21]$. The genetic alterations and global changes in gene expression can be considered at three distinct levels, i.e., genomic, transcriptomic, and proteomic (Figure 1), where every level presents respective unique advantages and limitations. The analysis of complex interactions among the above-mentioned molecular levels forms the basis for understanding of personalized oncology [22].

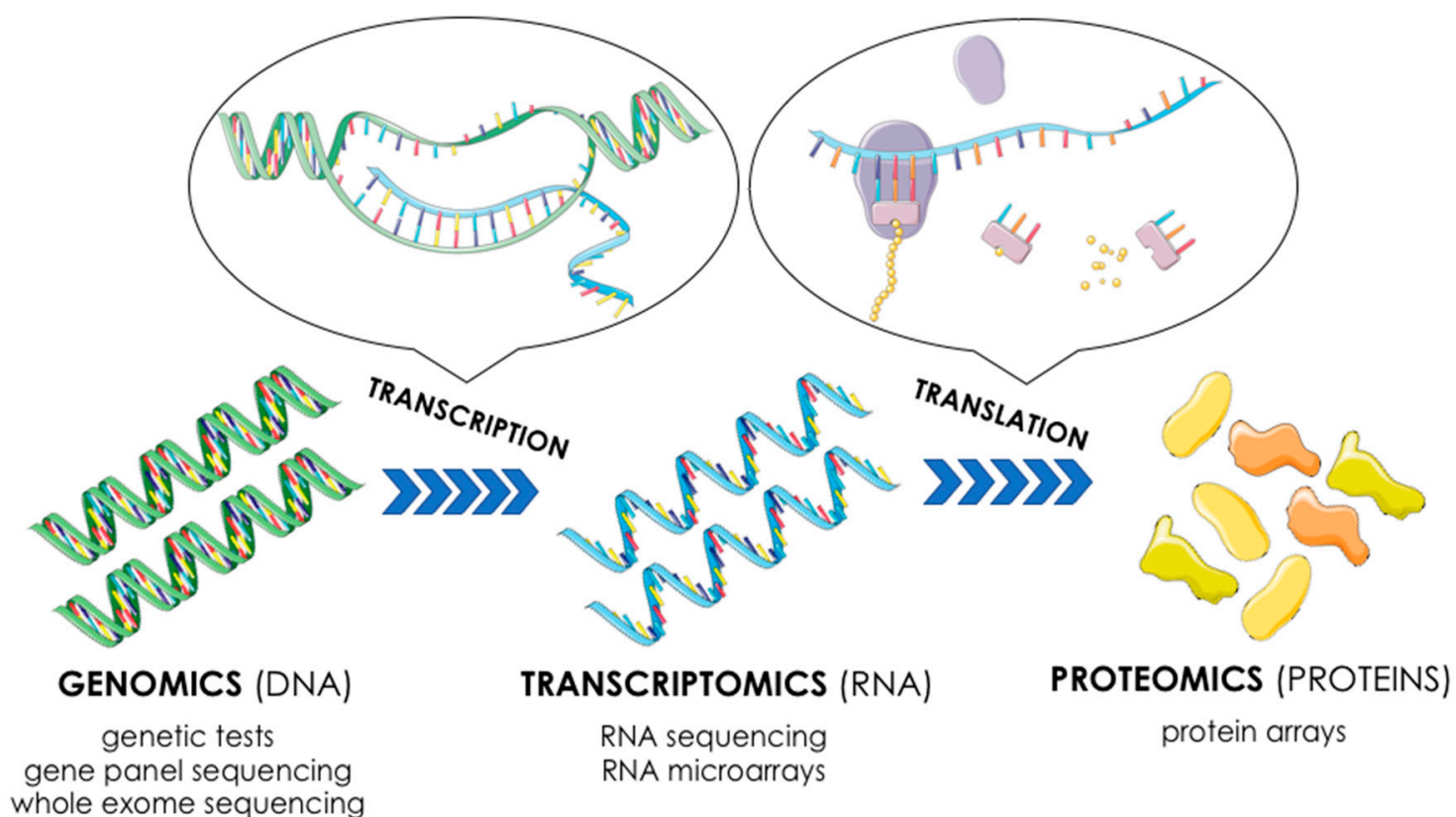

Figure 1. Omics—different approaches to gene expression (based on [22]). This figure was created using images from Servier Medical Art Commons Attribution 3.0 Unported License. (http:/ / smart.servier.com). Servier Medical Art by Servier is licensed under a Creative Commons Attribution 3.0 Unported License.

The genomic level can be regarded as the farthest from the cellular phenotype. Since the human genome was sequenced, the major progress has been made in research of mutations driving cancer cells [23]. Specific mutations responsible for malignant transformation and hereditary cancer syndromes were identified [24]. Despite the advantages of DNA sequencing, the mutation assays present strong limitations in personalized medicine [25]. First of all, only a small percentage of human genome is expressed to the protein level. Secondly, gene expression is a very complicated and multistage process, controlled by numerous regulating mechanisms, such as DNA methylation [26], DNA-binding proteins [27], or small interfering RNA (siRNA) [28]. Moreover, molecular studies, as well as karyotyping and genomic hybridization revealed cancer cell heterogeneity. It was discovered that cells within the same tumor may vary so significantly in terms of DNA sequence to the point of defining different subpopulations, implicating clinical heterogeneity [29,30]. Furthermore, plasticity of cancer genomes manifesting itself in cell-to-cell DNA sequence variability (observed during tumor development and induced by treatment), precludes the achievement of large-scale clinical benefits [31]. In conclusion, the analysis of cancer genome 
may provide valuable information on the DNA sequence and its structure, but could be inadequate to describe the actual phenotype of the cell [22]. Therefore other approaches are needed to find proper molecular diagnostic targets and to address specific therapy for cancer patients.

The proteomic approach, which is obviously closer to the molecular mechanisms determining cell's phenotype than genomics [32], focuses on quantitative protein measurements to characterize biological processes and deciphers the protein-dependent mechanisms of gene expression regulation in a living cell $[33,34]$. It is confirmed that proteins are the key factors in all cellular processes, while mutations alter their expressions and/or activities in various ways $[35,36]$. The analysis of the cancer proteome enables to obtain a landscape of post-translational modifications, interactions between cellular mechanisms and their locations [37]. Among techniques of protein recognition, microarrays are the most frequently employed. This method uses monoclonal antibodies or other binders for identification of an individual protein. Protein microarrays have gained extensive applications in molecular diagnostics, particularly in cancer biomarker discovery [33]. Nevertheless, technical difficulties related to the method, such as different physical and chemical properties of proteins, as well as the need of usage of highly specific antibody panels, are the significant obstacles for proteomic studies in a wide range [38].

The pivotal link between cellular phenotype and genetic aspects of tumor biology is transcriptome. It contains all information encoded in RNA transcribed from DNA. In contrast to the genome which is relatively stable, transcriptome reacts actively to the physiological or pathological conditions. Adjustments in the transcriptome reflect the different cell states, developmental stages, and regulatory mechanisms [15]. Nowadays, transcriptomics have come to the forefront of international scientific attention due to the rapid development of RNA-sequencing (RNA-Seq) methods.

\section{Transcriptome's Components and Methods of Its Analysis}

Studies show that about $93 \%$ of the human DNA is transcribed into RNA, however only $2 \%$ into pcRNA [4]. These molecules, in a mature form, specify the sequence of amino acids in the protein and participate in translation. The remaining part of the human transcriptome consists of ncRNA and, out of all discovered until now, include: ribosomal RNA (rRNA), transfer RNA (tRNA), micro RNA (miRNA), small interfering RNA (siRNA), PIWIinteracting RNA (piRNA), small nuclear RNA (snRNA), small nucleoar RNA (snoRNA), extra-cellular RNA (exRNA), guide RNA (gRNA), small Cajal body-specific RNA (scaRNA), circular RNA (circRNA), long non-coding RNA (lncRNA), such as X-inactive specific transcript (XIST) and HOX Transcript Antisense RNA (HOTAIR) [39]. Their cellular functions significantly differ from each other. Some ncRNAs present catalytic roles, e.g., involved in production of tRNA and rRNA; whereas other participate in controlling mRNA, e.g., miRNA, snRNA, snoRNA [40].

All the above-mentioned ncRNA types potentially contribute to oncogenesis. Moreover, previously unknown types of RNAs are being continuously discovered-mostly due to modern technologies. Meticulous analysis of RNAs' functions and the development of novel techniques may lead to the improvement of transcriptome cognition.

\subsection{History of Gene Expression Measurement Methods}

Several technologies have been developed to define the role of all RNAs forming transcriptome in human diseases. The first approach of studying human transcriptome ascribes to quantification of mRNA with Northern blotting [41,42]. This time-consuming method uses gene-specific DNA probes which are hybridized to the RNA and is capable of analyzing a maximum a few gene transcripts at the same time [43].

Subsequently newer methods based on complementary probe hybridization were introduced to transcriptome analysis [8]. Today, three main directions can be distinguished in cancer transcriptomics: microarrays, large-scale quantitative reverse-transcription- 
polymerase chain reaction (qRT-PCR) (both using probe hybridization), and the newest, next-generation sequencing (NGS) technology, represented by RNA-Seq [8,44].

\subsubsection{Microarrays}

Microarray technology gained wide approval since its discovery in mid-1990s and this method quickly became the most frequently used for transcriptome profiling [45,46]. A microarray is a collection of microchips of microbeads containing DNA probes (nucleotide oligomers) corresponding to known sequences. RNA is isolated from the control and the target samples, undergo reverse transcription and labeling and then cDNA is hybridized to a microarray. The abundance of hybridization is quantified by fluorescently labelled probes and the results are adapted to measure the expression levels [47] (Figure 2). Microarrays found a wide usage also in the research of tumor mRNA, particularly enabled the identification of differentially expressed genes involved in key molecular pathways and discovery of numerous cancer biomarkers [48,49]. Although the measurement of mRNA down- or upregulation with microarrays is a powerful tool for analyzing gene expression and molecular behavior of transcriptome, the results may vary significantly depending on microarray platforms, type of laser scanners, laboratories procedures and analytical methods [50]. Therefore, analysis of mRNA expression with microarrays should be considered as a preliminary step, and verified by RT-PCR or immunohistochemical analysis [51].

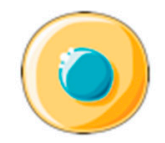

normal cell - control sample

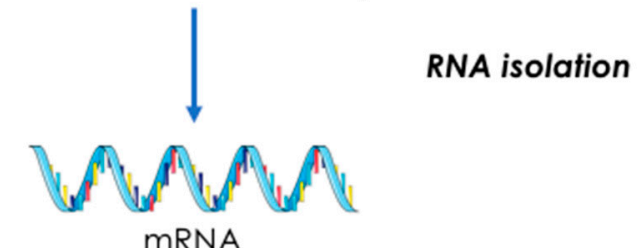

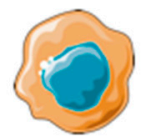

cancerous cell - test sample

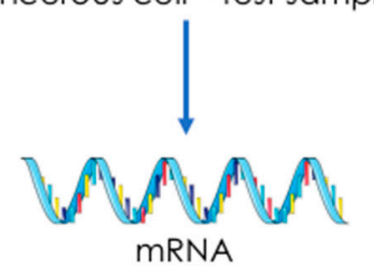

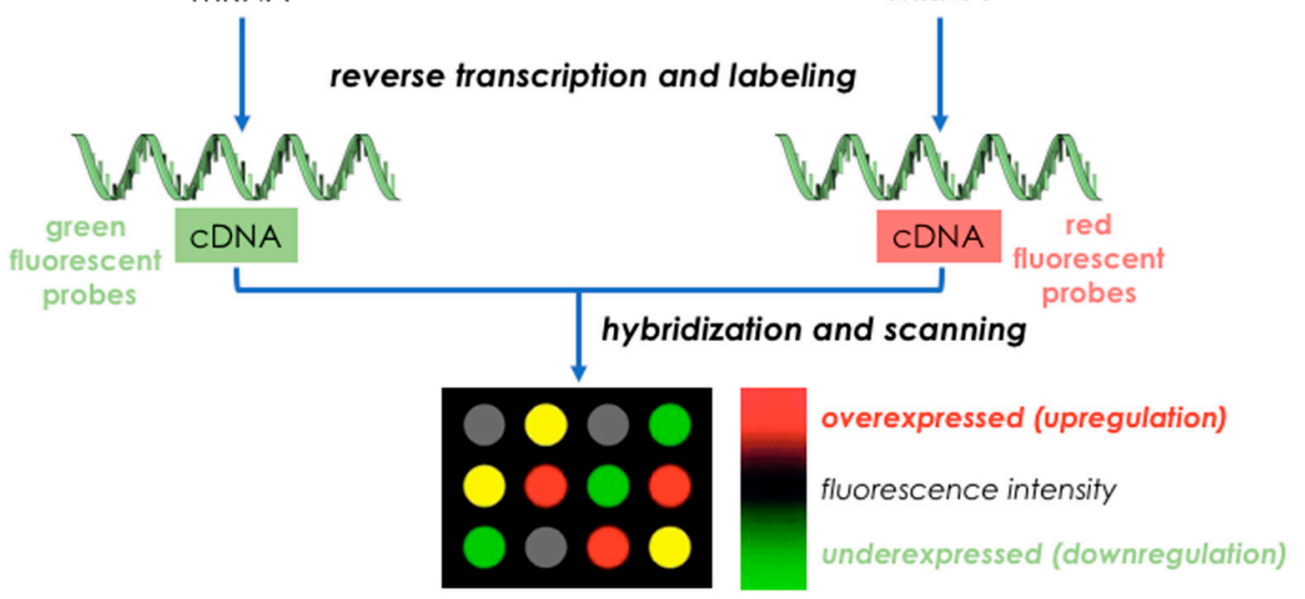

Figure 2. An overview of DNA microarray technology (based on [47]). This figure was created using images from Servier Medical Art Commons Attribution 3.0 Unported License. (http://smart.servier.com). Servier Medical Art by Servier is licensed under a Creative Commons Attribution 3.0 Unported License.

\subsubsection{Large-Scale Real-Time Reverse Transcription PCR}

Another technique that was involved in transcriptome profiling is large-scale realtime (quantitative) reverse transcription PCR (RT-PCR). The method was first successfully applied for verification of microarray RNA analysis, and thereafter it has been extended 
to become a self-sufficient technique as it is fast, reliable and enables the accurate and simultaneous profiling of many genes expression $[4,52]$. It is noteworthy that RT-PCR found broad applications in diagnostics and treatment monitoring in oncology [53]. It has been used in research of prognostic and predictive tumor biomarkers, e.g., in breast cancer [54], melanoma [55,56], or hepatocellular carcinoma [57,58], as well as for other purposes, such as micrometastasis determination [59] or detection of circulating tumor cells $[60,61]$. In this method complementary DNA (cDNA) is generated from RNA template in reverse transcription and specific DNA targets are amplified using polymerase chain reaction (PCR), employing large set of primer pairs. Quantitative PCR enables to evaluate the increase in copies of investigated sequences in real time. It is possible due to labelling of primers, oligonucleotides, or amplification products with fluorophores. A positive reaction is detected by the accumulation of a fluorescent signal.

\subsubsection{RNA-Sequencing (RNA-Seq)}

Above-mentioned hybridization-based methods are limited by the need of prior knowledge on the sequence of the probed nucleic acid [62]. Therefore, transcriptomics evolved to sequencing-based techniques including consecutively: Sanger sequencing of expressed sequence tags (ESTs) and NGS.

Sanger sequencing is a method of controlled termination of DNA synthesis [63]. A sample matrix is usually single-stranded DNA amplified in PCR [64]. The sequencing process requires the sample matrix, DNA polymerase, one primer, four deoxynucleotidetriphosphates (dNTPs) and four fluorescent labelled dideoxynucleotidetriphosphate (ddNTPs). DNA polymerase is applied for synthetizing nucleic acid strand using either dNTPs, which enables continuation of synthesis, or ddNTPs, which terminates further synthesis in a specific locus [65]. For the purpose of RNA studies, ESTs-short sub-sequences of cDNA complementary to a part of mRNA—are used with Sanger sequencing [8]. Before NGS technology was introduced, tag-based sequencing had been commonly used in the research of tumor biomarkers [66-68]. Nevertheless, it presents significant limitations: it can sequence short pieces of DNA - up 1000 base pairs, the primer's template must be defined and there has to be large amount of copies of the gene in the starting mixture for sequencing [69].

\subsubsection{Next Generation Sequencing (NGS)}

The new era of transcriptome profiling is set by the NGS. It provides abundant possibilities to perform simultaneous investigations of thousands of genes, analyses of complicated molecular mechanisms participating in oncogenesis and thus, offers a great contribution to the precision medicine. NGS technology, first introduced in 2004, may be applied in various areas: whole-genome and exome sequencing, RNA-Seq, which is referred today as a "gold standard" of transcriptome analysis, chromatin immunoprecipitation followed by sequencing (ChIP-Seq) for analysis of interactions between DNA and proteins and copy number variation-sequencing (CNV-Seq) to analyze DNA copy number variation [70]. RNA-Seq enables high-throughput gene expression analysis with remarkable precision. NGS generates data about splicing variants, allelic expression and RNA editing [71]. It enables the analysis of epigenetic modifications and elements playing role in mechanisms, such as ncRNAs [72]. This technology has significantly increased the efficiency, sensitivity, accuracy and transcript coverage in obtained results in comparison to microarrays [73].

Several NGS platforms are based on the pyrosequencing principle, where binding of nucleotides during chain synthesis is monitored by luminescence [74]. After the incorporation of a specific dNTP, a lightning signal is generated when pyrophosphate (PPi) is converted to ATP by ATP sulfurylase in the presence of adenosine $5^{\prime}$ phosphosulfate (APS). Two sequencing platforms directly utilize pyrosequencing principle: 454 Sequencing (454 Life Sciences; now Roche Holding AG, Basel, Switzerland) and PyroMark ID system (Qiagen, Hilden, Germany) [75,76]. Other massive parallel sequencing instruments include: Illumina-Solexa Genome Analyzer family launched in 2006, Ion Torrent, Thermo Fisher and Bionano Technologies [77]. Considering main differences between analyzers, Roche 
display higher length reads in comparison to Illumina, but produce more errors within homopolymer regions [78,79].

RNA-seq has been widely used for the research on gene expression in various malignancies and has been found as an effective tool in exploration of carcinogenesis, identification of tumor biomarkers and development of new therapeutic strategies. The following parts of the article provide a clearer image of the achievements of transcriptomics over the recent years.

\section{Applications of Transcriptome Analysis in Oncology}

The transcriptome-based studies opened a new chapter in molecular understanding of cancer. Analysis of gene expression allows researchers to explore molecular basis of cancer in a multiway manner and provides information of tumor progression. Technologies involved in transcriptomics have expanded our knowledge on carcinogenesis, tumor microenvironment (TME), and immuno-oncology, as well as enabled the discovery of new, previously unknown cancer biomarkers.

\subsection{Applications in Clinical Classifications of Cancer}

Identification of the molecular portrait of the tumor is valuable in cancer classification and elucidation of biochemical pathways, which allows further selection of selective therapeutics and prediction of cancer drug sensitivity [80]. Analysis of the transcriptome has led to a significant improvement in clinical classification of many tumors [81,82].

So far, numerous studies have been carried out to profile gene expression and thus, to establish molecular classification and identification of therapeutic/diagnostic targets in breast cancer [83-86]. One of the first successful attempts of gene expression-based characterization was made by Perou et al. (2000). In 65 samples of breast cancer obtained from 42 patients, unique patterns of gene expression were observed for every individual [87]. Nevertheless, four different molecular clusters of breast cancer, presenting similar expression signatures, were captured: ER+/luminal-like, basal-like, Erb-B2+ (Her-2/neu) and normal-like breast tumors. The clusters distinguished in this study correspond closely to immunohistochemistry markers of breast tumors: estrogen receptors, Her-2 and Ki-67 [88], and thus, should be treated as distinct diseases [89,90]. Moreover, similar conclusions were drawn in the study of Sørlie et al. [91], where luminal type of breast cancer was divided into two subtypes: luminal A (with high estrogen receptor expression and low expression of proliferative markers, e.g., Ki67) and luminal B (presenting lower estrogen receptor expression and high level of expression of proliferation-related genes) $[92,93]$. The above-mentioned studies were carried out by using microarray technology, which laid the foundations of current clinically used molecular classification of breast cancer [94].

Analogous efforts were made in classification of colorectal cancer (CRC). In the research conducted by Guinney et al., four consensus molecular subtypes of CRC were distinguished: CMS1 (microsatellite instability immune-hypermutated, characterized by strong immune activation, microsatellite unstable), CMS2 (canonical—marked by WNT and MYC signaling pathways activation), CMS3 (metabolic - epithelial with evident metabolic dysregulation), and CMS4 (mesenchymal - with growth factor- $\beta$ activation, stromal invasion and angiogenesis) [95]. Recently, many clinical trials demonstrated the usability of this classification, confirming different sensitivities to the treatment, recurrence parameters and tendencies to metastasis of individual CMS subtypes [96-100]. Such an approach aids in the understanding of CRC etiology for the purposes of precision oncology. However, further population-based trials must be performed to prove the advantages of introducing CMS classification into clinical oncology [84,101].

Another study uncovered differences in origin of ovarian cancer. It is pathologically divided into subtypes: epithelial (EOC), sex-cord stromal and germ cell, where EOC is subdivided into: high-grade serous, low-grade serous, mucinous, endometrioid and clear cell carcinoma [102]. According to the classic view on high-grade serous ovarian cancer (HGSOC), it originates from epithelial cells of ovarian surface. However, recent studies 
show that tumor may develop from fallopian tube [103,104]. The molecular profiling of HGSOC has revealed overexpression of PAX8, which is typical for cells within the distal fallopian tube $[105,106]$. The determination of PAX8 overexpression by using RNA-Seq may accelerate diagnostics.

Other attempts of classifying cancers based on their gene expression signatures have been made (among others) in uveal melanoma [107], small round-blue cells tumors (neuroblastoma, rhabdomyosarcoma, non-Hodgkin lymphoma, Ewing tumor) [108], large cell lung cancer [109], and head and neck squamous cell carcinoma [110] (Table 1).

Table 1. Examples of transcriptome-based molecular classification of particular malignancies.

\begin{tabular}{|c|c|c|}
\hline Cancer Type Based on Origin Tissue & Molecular Classification & Reference \\
\hline \multirow{6}{*}{ Breast cancer } & ER+/luminal-like & \multirow{4}{*}{ [87] } \\
\hline & Basal-like & \\
\hline & Erb-B2+ & \\
\hline & Normal-like & \\
\hline & Luminal A & \multirow{2}{*}{ [91] } \\
\hline & Luminal B & \\
\hline \multirow{4}{*}{ Colorectal cancer } & CMS1 (microsatellite instability immune) & \multirow{4}{*}{ [95] } \\
\hline & CMS2 (canonical) & \\
\hline & CMS3 (metabolic) & \\
\hline & CMS4 (mesenchymal) & \\
\hline \multirow{4}{*}{ Gastric adenocarcinoma } & EBV positive & \multirow{4}{*}{ [111] } \\
\hline & MSI high & \\
\hline & GS & \\
\hline & CIN & \\
\hline \multirow{6}{*}{ Glioblastoma } & Poor (invasive) & \multirow{3}{*}{ [112] } \\
\hline & Favorable (mitotic) & \\
\hline & Intermediate & \\
\hline & Proneural & \multirow{3}{*}{ [113] } \\
\hline & Mesenchymal & \\
\hline & Proliferative & \\
\hline
\end{tabular}

\subsection{Identification of Early Detection Cancer Biomarkers}

There is an urgent need to find new early diagnosis and treatment monitoring biomarkers for most of tumors. For instance, the usefulness and clinical reliability of carbohydrate antigen 125 (CA125), which is the most commonly utilized serum biomarker of ovarian cancer remain controversial [114]. The specificity of CA125 ranges between $35 \%$ and $91 \%$ [115]. CA125 level is raised only in approximately $50 \%$ of early onset ovarian cancer cases and up to $90 \%$ at advanced stage [116]. The study of Mosig et al., performed with the RNA-Seq-based transcriptome analysis of 22 samples from ovarian cancer patients, showed significant overexpression of insulin-like growth factor binding protein-4 (IGFBP-4). The IGFBP-4 transcript level was elevated in initial and advanced disease phase as well as in relapse samples, regardless of CA125 levels [117].

Another example of utilization of gene expression profiling in the selection of cancer biomarkers can be found in gastrointestinal tract tumors. Despite the development of multidisciplinary treatment of esophageal cancer, the clinical outcomes often remain insufficient due to late diagnosis of the disease [118]. Hence, the discovery of relevant biomarkers enabling early screening is of high importance. Currently, the most commonly 
used biomarkers in esophageal squamous cell carcinoma (ESCC) diagnosis are: cytokeratin 19 fragment antigen 21-1 (Cyfra21-1), carbohydrate antigen 19-9 (CA19-9), carbohydrate antigen 72-4 (CA72-4), carcinoembryonic antigen (CEA), and squamous cell carcinoma antigen (SCC-Ag) [119]. The above-mentioned proteins are characterized by high specificity for ESCC, but low sensitivity ranging between 10\% and 40\% [120]. Recent approaches combine mRNA sequencing or proteome sequencing together with computational analysis, have identified highly expressed genes or highly secreted proteins, which may serve as early detection biomarkers. Bioinformatics enables parallel analysis of thousands of variables in the genome-wide scale, assess their significance, which facilitates selection of relevant variables and allows for biologically meaningful interpretations [121]. However, chemistry, sequencing, and data preprocessing differ significantly between proteome sequencing and mRNA sequencing, the downstream steps are similar [122]. Statistical comparisons of normal tissue, benign neoplasia and tumor tissue by data mining methods represent a common way of searching and prioritization of biomarkers [123]. Regarding statistical analyses used to compare various stages of neoplasia, there are a huge variety of data mining methods including relatively simple feature (gene) selection algorithms (e.g., $\mathrm{t}$-test, principal component analysis (PCA), nucleoside triphosphate (NTP) classifier and least absolute shrinkage and selection operator (LASSO)) or more mathematically sophisticated approaches (e.g., support vector machine (SVM)-based, Bayesian network-based, neural network-based, or ensemble-based) [124]. It has to be emphasized that difference in terms of performance (specificity, sensitivity, accuracy) is comparable between these two classes of mining methods (simple and sophisticated). Therefore, in current biomarker research simple solutions such as NTP classifier became popular $[125,126]$. Moreover, sets of selected markers offer much better performance than single marker, therefore, currently in various studies predictive power have benefited from such multi-marker approach [127]. For example, in the study of Xing et al., three serum markers were evaluated as potentially clinically usable: CHI3L1, MMP13, and SPP1, from more than 4000 differentially expressed genes in the ESCC transcriptome database. The diagnostic panel using combination of CHI3L1, MMP13 and SPP1 identified approximately 90\% of cases with early-onset ESCC, where the panel's detectability in non-cancerous tissues ranged between $10 \%$ and $15 \%$ [128].

Moreover, various RNA molecules may serve as independent cancer biomarkers [129]. Over the recent years, many RNAs were found to be useful in precision oncology (Table 2). For instance, the expression profile of snoRNAs [130] and 4-miRNA expression signature [131] can be used in early diagnosis of non-small-cell lung carcinoma (NSCLC). In addition, miR-106b, miR-20a, and miR-221 were confirmed as early detection biomarkers for gastric cancer $[132,133]$. The piRNAs, which mediate transcriptional and posttranscriptional gene silencing machineries, may serve as biomarkers for early diagnosis, treatment and prognosis of: renal cancer [134,135], hepatocellular carcinoma [136], glioblastoma [137] and gastric cancer [138]. Moreover, lncRNAs, such as XIST, present as potential candidates for the detection of early gastric cancer [139]. A growing number of studies have indicated the possibility of applications of ncRNAs in CRC as well $[140,141]$. 
Table 2. Potential cancer biomarkers discovered through transcriptome analysis.

\begin{tabular}{|c|c|c|c|}
\hline Cancer Type & Biomarkers & Expression in Cancer Tissue * & Reference \\
\hline \multirow[t]{2}{*}{ Breast cancer } & $\begin{array}{l}\text { miR-126-5p, miR-144-5p, miR-144-3p, } \\
\text { miR-301a-3p, miR-126-3p, miR-101-3p, } \\
\text { miR-664b-5p }\end{array}$ & up/down & [142] \\
\hline & LINC00657 (lncRNA) & up & [143] \\
\hline \multirow{4}{*}{ Colorectal cancer } & ABCD3 & down & [144] \\
\hline & $\begin{array}{l}\text { piR-5937, piR-28876, piR-23210, } \\
\text { piR-32159 }\end{array}$ & down & [140] \\
\hline & miR-17-92a, miR-135 & up & [145] \\
\hline & $\operatorname{miR}-21$ & up & [141] \\
\hline Esophageal cancer & CHI3L1, MMP13, SPP1 & up & [128] \\
\hline Gallbladder carcinoma & BIRC5 & up & [146] \\
\hline \multirow{4}{*}{ Gastric cancer } & $\begin{array}{l}\text { miR-106b, miR-20a, miR-21, } \\
\text { miR-221, miR-451 }\end{array}$ & up & [132] \\
\hline & miR-17-5p, miR-21, miR-106a, miR-106b & up & [147] \\
\hline & $\begin{array}{l}\text { miR-1, miR-20a, miR-27a, } \\
\text { miR-34a, miR-423-5p }\end{array}$ & up & [148] \\
\hline & piR-651 & down & [138] \\
\hline \multirow{2}{*}{ Glioblastoma multiforme } & Thymosin $\beta 4$ (TMSB4X), S100A10 & up & [149] \\
\hline & miR-20a, miR-106a & up & [150] \\
\hline Hepatocellular cancer & piR-013306 & up & [136] \\
\hline Hogdkin lymphoma & piR-651 & down & [151] \\
\hline \multirow[t]{2}{*}{ Melanoma } & $\begin{array}{l}\text { Ro-aassociated Y RNA (YRNAs): } \\
\text { RNY3P1, RNY4P1, RNY4P25 } \\
\text { (upregulation) } \\
\text { miR-320a-3p, miR-134-5p } \\
\text { (downregulation) }\end{array}$ & up/down & [152] \\
\hline & miR-21 & up & [153] \\
\hline Multiple myeloma & piR-823 & up & [154] \\
\hline \multirow{3}{*}{ Non-small cell lung carcinoma } & 4-miRNA & up & [131] \\
\hline & snoRNA & up & [130] \\
\hline & 34 miRNA expression signature & up/down & [155] \\
\hline Ovarian cancer & IGFBP-4 & up & [117] \\
\hline \multirow{2}{*}{ Pancreatic cancer } & KRAS mRNA (as salivary biomarker) & up & [156] \\
\hline & LAMC2 & up & [157] \\
\hline Renal cancer & PIWIL1, piR-823 & down & [158] \\
\hline
\end{tabular}

* up-upregulated; down-downregulated.

The cancer cells for molecular analyses may be obtained directly from cancer tissue, from peripheral blood [159] and (depending on the tumor primary locus) from other specimens, e.g., sputum $[160,161]$. In recent years, an emerging field of future cancer diagnostics is liquid biopsy-unique sampling of neoplastic material from the blood. Two main directions can be distinguished for studies on liquid biopsy: analysis of circulating tumor cells (CTCs) and analysis of circulating nucleic acids. The first approach is limited by the uncommonness of cancer cells in the bloodstream (around one CTC per billion blood cells) [162], which significantly reduce the clinical application of this method. Alternatively, analysis of nucleic components of tumor cells—cell free DNA (cfDNA) and circulating RNA 
(circRNA, including miRNA) - is gaining an increasing interest, demonstrated in numerous studies and clinical trials [159,163-165]. Rapid advancement of novel technologies, enables to detect cancerous DNA/RNA with high accuracy for diagnosis, prognosis and therapeutic monitoring [166]. RNA monitoring, in comparison to DNA-based biopsy, presents two main advantages: it is a better tool for identification of gene fusions and functional disease profiling, through detection of ncRNA of biological importance and characterization of alternative RNA splicing products $[167,168]$. Consequently, a number of recent studies involving RNA obtained from liquid biopsy is steadily increasing (mostly for miRNA markers). Results of large, carefully conducted validation studies (sample sizes above 500) showed promising opportunities of applying miRNA signatures in clinics in the near future. For example, miR-Test published in 2015 is based on signature of 13 serum miRNAs for early and sensitive detection of lung cancer. MiR-Test displayed the sensitivity of $77.8 \%$ and the specificity of $74.8 \%$ to detect lung tumors [169]. There are also several urine-based tests for detection of prostate cancer including SelectMDx (based on gene expression signature) and Progensa PCA3 (based on lncRNA expression signature) [170,171]. Both tests revealed their potential in elimination of unnecessary prostate biopsies [172].

\subsection{Creation of Cancer Prognostic and Predictive Panels}

Various assays based on gene expression analysis have been developed to guide personalized therapeutic pathway in oncology [22]. Multigene tests provide detailed insight into cancer biology with simultaneous information on expression of relevant, prognostic fundamental genes. Some assays are already used in diagnosis, as prognostic panels and for the prediction of treatment effects (mostly adjuvant or neoadjuvant systemic therapy) [173].

Among most commonly used gene expression tests are MammaPrint ${ }^{\circledR}$ and Oncotype $\mathrm{DX}^{\circledR}$ assessing the risk of relapse and metastasis in breast cancer. MammaPrint ${ }^{\circledR}$ is 70gene panel, tested in large randomized controlled trial (MINDACT, ClinicalTrials.gov identifier: NCT00433589), where its ability to differentiate low-risk and high-risk patients with breast cancer was confirmed $[174,175]$. Oncotype DX ${ }^{\circledR}$ is 21-gene qRT-PCR test assessing the risk of breast cancer recurrence, with particular emphasis on early-stage, ERpositive (estrogen receptor), HER2-negative and axillary node-negative tumors [176]. The advantages of Oncotype DX ${ }^{\circledR}$ panel were presented widely in trial TAILORx (ClinicalTrials. gov identifier: NCT00310180) [177]. Other transcriptomic signatures of breast cancer with clinical usage are: Prosigna ${ }^{\circledR}$-Assay (PAM50-50-gene panel) $[178,179]$, Endopredict ${ }^{\circledR}$ (12-gene assay) [180,181].

The similar assays are being tested in prognosis of colon cancer. The twin test of Oncotype DX ${ }^{\circledR}$ used in breast cancer - 12-gene Oncotype DX ${ }^{\circledR}$ Colon Cancer Assay identifies the tumors with high risk of recurrence and helps to determine the necessity of implementation of adjuvant systemic therapy [182-184]. In the study of Aziz et. al, the 19-gene signature was evaluated as a predictive classifier in colorectal cancer using microarray profiling [185]. It was revealed that the patients assigned into the low-risk group could avoid or receive lower concentrations of adjuvant chemotherapy.

Afirma ${ }^{\circledR}$ gene expression classifier is a microarray assay used for thyroid cancer diagnosis. It is validated as pre-operative test for differentiating invasive cancer from benign nodules (such as follicular adenoma) in order to avoid unnecessary surgeries [186]. The cytological tests used routinely for attaining that purpose are characterized by frequent false results, therefore genetic testing is valuable solution for this problem [187]. Other diagnostic panels are: ThyroidPrint ${ }^{\circledR}$ (10-gene classifier) [188], ThyroSeq v3 (DNA- and RNA-based NGS assay analyzing 112 genes) [189], RosettaGX Reveal, and ThyraMIR/ThyGenX ${ }^{\mathrm{TM}}$, which are respectively 24-miRNA and 10-miRNA (with 8 DNA mutations) expression tests $[190,191]$. 


\subsection{Intratumoral Heterogeneity (ITH) and Tumor Microenvironment (TME)-Related Research}

Most of human cells have identical DNA material, despite the differences at the level of gene expression. For example, transcriptome and protein landscapes of the liver vary significantly from those of the heart. In addition, such cellular differences can be distinguished within the same organ, e.g., neurons and glial cells of the brain. These differences in gene expression within particular subpopulations of cells reflect their distinct morphologies, functions, regenerative capacities, etc. Thus, profiling of transcriptome of individual cells-single-cell RNA-Seq (scRNA-Seq)—provides a multidirectional insight into specific cell's functions-also in cancer. The scRNA-Seq is valuable but challenging method preceded by dissociation of heterogenous tissue and optimized filtering [192]. To date, this approach has enabled identifications of novel cell populations and cell-cell interactions. The characterization of ITH reveals the molecular background for resistance to the cancer treatment, the dynamic of tumor growth and its potential of relapse [193]. Several works show the power of scRNA-Seq to distinguish the ITH. The study of Sharma et al. revealed the multi-level tumor evolution of lung squamous cell carcinoma based on cell subclones closely related to tumor-immune cell interactions [194]. In the study of Wu et al., the immunological interactions between breast cancer cells and TME were proved, showing the ability of scRNA-Seq for analyzing tumor in a dynamic state [195].

Intra-tumor heterogeneity generates serious complications, including resistance to therapy. In addition to the different subpopulations forming a tumor bulk, the response to the treatment and whole disease course are dependent, among others on the interactions within TME. It consists of complex ecosystem of stromal cells, such as cancer-associated fibroblasts (CAFs), immune cells, endothelial cells and others of lesser importance. As mentioned above, TME components actively influence tumor cell proliferation. For example, cytokines secreted by CAFs participate in signal pathways in cancer cells [196]. Moreover, the immune compartment of TME acts immunosuppressively, creating a barrier between cancer cells and the host's immune system [197]. The investigation of mechanisms by which TME affects cancer biology is possible through leverage of gene expression profiling.

The technology which has been successfully applied in the studies of TME of the recent years is RNA-seq [198]. It has become an integral tool of immunogenomics and serves today for analysis of gene expression patterns associated with the presence of different populations of immunological cells in the cancerous tissue [199]. Identification of distinct immune and stromal cells subtypes enables not only for understanding of different metabolic phenotypes of tumors, but also for the assessment of immune receptor repertoire in purpose of precision cancer immunotherapy [200]. The T-cell receptor (TCR)/B-cell receptor (BCR) sequences on tumor cells provide an information about specificity of immune response in TME. This landscape of TCRs/BCRs may serve as a predictive biomarker of the effectiveness of immunotherapy [201,202]. However the validation cohorts of these gene signatures remains to be seen.

\subsection{RNA-Based Therapeutics}

Dynamic growth of knowledge on transcriptome has changed a simple understanding of RNA as an intermediary between DNA and protein to a whole variety of molecules with numerous functions and a potential of regulation of gene expression. Thus, particular RNAs can be used as therapeutic targets as well. The greatest progress in terms of RNAbased therapies has been made in regard to miRNA.

miRNAs, which selectively induce mRNA degradation and translation inhibition, present an abnormal expression within cancerous tissues. Depending on their functions, miRNAs may act as an oncogenes (also known as oncomiRs-Onc miRNAs) or tumor suppressors (TS miRNAs) [203]. OncomiRs (e.g., miR155 and miR21) promote cell transformation, carcinogenesis, and metastasis by blocking the expression of tumor suppressor genes, and hence can be used as therapeutic targets in cancer treatment [204-206]. In turn, TS miRNAs suppress the translation of mRNAs involved in oncogenic pathways. Many studies have confirmed that the expression of TS miRNAs are downregulated in 
cancer $[207,208]$. Therefore, miRNAs can be considered as an early indicator for diagnostic purposes and patient prognosis, as well as effective target for therapeutic strategies in oncology [203].

There are two main approaches for regulating miRNA activities: suppression of expression of oncogenic miRNAs, and restoration of the loss of TS miRNAs' expressions [203,209]. Inhibition of oncomiRs' expressions can be achieved through the use of antisense oligonucleotides with 2'-O-methyl groups [210-212], 2'-O-methoxyethyl groups [213] and other linkages blocking exonuclease degradation, such as $\mathrm{N}, \mathrm{N}$-diethyl-4-(4-nitronaphthalen-1ylazo)-phenylamine [214]. Another strategy is an application of locked nucleic acid (LNA) anti-miRNA oligonucleotides with complementary sequences to target miRNAs [206,215]. Currently, two clinical trials, i.e., SOLAR (ClinicalTrials.gov identifier: NCT03713320; miRagen Therapeutics, Inc., Boulder, CO, USA) and PRISM (enrolling; ClinicalTrials.gov identifier: NCT03837457), investigate the efficacy and safety of Cobomarsen (MRG-106) —an LNA antimiR $^{\circledR}$ inhibitor of miR-155 in the treatment of cutaneous T-cell lymphoma (CTCL), adult T-cell lymphoma (ATLL), chronic lymphocytic leukemia (CLL) and diffuse large B-cell lymphoma (DLBCL) [216-218].

The approach focusing on restoration of down-regulated TS miRNAs is called miRNA replacement therapy [219]. It is based on delivery of key miRNAs for carcinogenesis using either viral or non-viral vectors [220]. Viral platforms have been found to be insufficient due to triggering of immune response [221]. Non-viral vectors include: inorganic miRNA platforms (e.g., $\mathrm{Fe}_{3} \mathrm{O}_{4}$-based nanoparticles [222], gold or nanodiamonds platforms [223], and silica-based systems [224]), polymer-based miRNA delivery systems (such as polyamidoamine dendrimers-PAMAMs $[225,226]$, or atelocollagen $[227,228])$ and lipid-based platforms $[229,230]$.

Considering the increase in RNA-focused studies over the recent years, the specific knowledge about RNA may result in introduction of clinical, RNA-based techniques [231]. Research efforts have focused on overcoming limitations related to RNA therapeutics: low bioavailability, poor cellular uptake or rapid elimination and excessive immune response [232,233]. Nevertheless, targeting RNAs networks in cancer present strong potential for future clinical utility. Therefore, a growth in RNA therapeutics in the next several years is highly expected.

\section{Conclusions}

Transcriptomics undoubtedly deserves to be considered as contemporary "gamechanger" in oncology on both molecular and clinical levels. In recent years, the revolution in the understanding, research, and clinical implementation of RNA-based techniques can be observed. The constant development of molecular technologies used for transcriptome analysis and implementation of NGS platforms considerably changed the landscape of RNA world research. RNA-seq is continuously gaining larger role in the clinical care of cancer patients, as well as preclinical research and basic science. It enables an insight into the molecular mechanisms underlying cancer, which has given rise to numerous trials related to transcriptome-based personalized oncology. The increasing availability of transcriptome profiling enables the introduction of transcriptomics in clinics. To date, several prognostic and predictive gene expression assays, as well as cancer biomarkers, have been utilized in clinical oncology. The change of the paradigm of cancer classification-from histopathological and clinical to molecular, opens a more personalized perspective for tumor diagnostics and therapy. The further advancement of transcriptomeprofiling will allow for standardization and the cost reduction of its analysis, which will be the next step for transcriptomics to become a canon of contemporary cancer medicine.

Author Contributions: S.S., conceptualization, investigation, writing-original draft, corresponding author; P.K., writing-review \& editing; M.S., writing-review \& editing, supervision, funding acquisition; I.L., writing-review \& editing, supervision, validation, project administration. M.S. and I.L. are equal contributors. All authors have read and agreed to the published version of the manuscript. 
Funding: This research was funded by Statutory Subsidy Funds of the Genetics Department, Wroclaw Medical University grant number no. SUB.A.290.19.020.

Institutional Review Board Statement: Not applicable.

Informed Consent Statement: Not applicable.

Data Availability Statement: Not applicable.

Acknowledgments: The study was supported by Statutory Subsidy Funds of the Genetics Department, Wroclaw Medical University no. SUB.A.290.19.020.

Conflicts of Interest: The authors declare no conflict of interest.

\section{References}

1. Unger, F.T.; Witte, I.; David, K.A. Prediction of individual response to anticancer therapy: Historical and future perspectives. Cell. Mol. Life Sci. 2015, 72, 729-757. [CrossRef] [PubMed]

2. Bezabeh, T.; Odlum, O.; Nason, R.; Kerr, P.; Sutherland, D.; Patel, R.; Smith, I.C. Prediction of Treatment Response in Head and Neck Cancer by Magnetic Resonance Spectroscopy. AJNR Am. J. Neuroradiol. 2005, 26, 2108-2113. [PubMed]

3. Sobin, L.H. TNM: Evolution and relation to other prognostic factors. Semin. Surg. Oncol. 2003, 21, 3-7. [CrossRef] [PubMed]

4. Casamassimi, A.; Federico, A.; Rienzo, M.; Esposito, S.; Ciccodicola, A. Transcriptome profiling in human diseases: New advances and perspectives. Int. J. Mol. Sci. 2017, 18, 1652. [CrossRef]

5. Wheeler, D.A.; Wang, L. From human genome to cancer genome: The first decade. Genome Res. 2013, 23, 1054-1062. [CrossRef]

6. López-Lázaro, M. A new view of carcinogenesis and an alternative approach to cancer therapy. Mol. Med. 2010, 16, 144-153. [CrossRef]

7. Janket, S.-J.; Qureshi, M.; Bascones-Martinez, A.; González-Febles, J.; Meurman, J.H. Holistic paradigm in carcinogenesis: Genetics, epigenetics, immunity, inflammation and oral infections. World J. Immunol. 2017, 7, 11. [CrossRef]

8. Lowe, R.; Shirley, N.; Bleackley, M.; Dolan, S.; Shafee, T. Transcriptomics technologies. PLoS Comput. Biol. 2017, 13, e1005457. [CrossRef]

9. Wang, Z.; Gerstein, M.; Snyder, M. RNA-Seq: A revolutionary tool for transcriptomics. Nat. Rev. Genet. 2009, 10, 57-63. [CrossRef]

10. Jacquier, A. The complex eukaryotic transcriptome: Unexpected pervasive transcription and novel small RNAs. Nat. Rev. Genet. 2009, 10, 833-844. [CrossRef]

11. Popov, X.D.V.; Makhnovskii, P.A.; Shagimardanova, E.I.; Gazizova, G.R.; Lysenko, E.A.; Gusev, O.A.; Vinogradova, O.L. Contractile activity-specific transcriptome response to acute endurance exercise and training in human skeletal muscle. Am. J. Physiol. Endocrinol. Metab. 2019, 316, E605-E614. [CrossRef]

12. Iwata, M.; Yuan, L.; Zhao, Q.; Tabei, Y.; Berenger, F.; Sawada, R.; Akiyoshi, S.; Hamano, M.; Yamanishi, Y. Predicting drug-induced transcriptome responses of a wide range of human cell lines by a novel tensor-train decomposition algorithm. Bioinformatics 2019, 35, i191-i199. [CrossRef] [PubMed]

13. Jaeger, P.A.; Doherty, C.; Ideker, T. Modeling transcriptome dynamics in a complex world. Cell 2012, 151, 1161-1162. [CrossRef] [PubMed]

14. Mallardo, M.; Poltronieri, P.; D'Urso, O.F. Non-protein coding RNA biomarkers and differential expression in cancers: A review. J. Exp. Clin. Cancer Res. 2008, 27, 19. [CrossRef] [PubMed]

15. Cieślik, M.; Chinnaiyan, A.M. Cancer transcriptome profiling at the juncture of clinical translation. Nat. Rev. Genet. 2018, 19, 93-109. [CrossRef]

16. Byron, S.A.; Van Keuren-Jensen, K.R.; Engelthaler, D.M.; Carpten, J.D.; Craig, D.W. Translating RNA sequencing into clinical diagnostics: Opportunities and challenges. Nat. Rev. Genet. 2016, 17, 257-271. [CrossRef]

17. Wang, L.; Acharya, L.; Bai, C.; Zhu, D. Transcriptome assembly strategies for precision medicine. Quant. Biol. 2017, 5, 280-290. [CrossRef]

18. Roychowdhury, S.; Chinnaiyan, A.M. Translating cancer genomes and transcriptomes for precision oncology. CA Cancer J. Clin. 2016, 66, 75-88. [CrossRef]

19. Patterson, A.D.; Gonzalez, F.J.; Perdew, G.H.; Peters, J.M. Molecular Regulation of Carcinogenesis: Friend and Foe. Toxicol. Sci. 2018, 165, 277-283. [CrossRef]

20. You, J.S.; Jones, P.A. Cancer Genetics and Epigenetics: Two Sides of the Same Coin? Cancer Cell 2012, 22, 9-20. [CrossRef]

21. Takeshima, H.; Ushijima, T. Accumulation of genetic and epigenetic alterations in normal cells and cancer risk. NPJ Precis. Oncol. 2019, 3, 1-8. [CrossRef] [PubMed]

22. Buzdin, A.; Sorokin, M.; Garazha, A.; Glusker, A.; Aleshin, A.; Poddubskaya, E.; Sekacheva, M.; Kim, E.; Gaifullin, N.; Giese, A.; et al. RNA sequencing for research and diagnostics in clinical oncology. Semin. Cancer Biol. 2019. [CrossRef] [PubMed]

23. Nussinov, R.; Jang, H.; Tsai, C.J.; Cheng, F. Review: Precision medicine and driver mutations: Computational methods, functional assays and conformational principles for interpreting cancer drivers. PLoS Comput. Biol. 2019, 15, e1006658. [CrossRef]

24. Thomas, E.; Mohammed, S. Advances in genetic testing for hereditary cancer syndromes. Recent Results Cancer Res. 2016, 205, 1-15. [CrossRef] 
25. Esplin, E.D.; Oei, L.; Snyder, M.P. Personalized sequencing and the future of medicine: Discovery, diagnosis and defeat of disease. Pharmacogenomics 2014, 15, 1771-1790. [CrossRef]

26. Jin, Z.; Liu, Y. DNA methylation in human diseases. Genes Dis. 2018, 5, 1-8. [CrossRef]

27. Smith, N.C.; Matthews, J.M. Mechanisms of DNA-binding specificity and functional gene regulation by transcription factors. Curr. Opin. Struct. Biol. 2016, 38, 68-74. [CrossRef]

28. Dana, H.; Chalbatani, G.M.; Mahmoodzadeh, H.; Karimloo, R.; Rezaiean, O.; Moradzadeh, A.; Mehmandoost, N.; Moazzen, F.; Mazraeh, A.; Marmari, V.; et al. Molecular Mechanisms and Biological Functions of siRNA. Int. J. Biomed. Sci. 2017, $13,48-57$.

29. Bedard, P.L.; Hansen, A.R.; Ratain, M.J.; Siu, L.L. Tumour heterogeneity in the clinic. Nature 2013, 501, 355-364. [CrossRef]

30. Gottlieb, B.; Babrzadeh, F.; Oros, K.K.; Alvarado, C.; Wang, C.; Gharizadeh, B.; Basik, M.; Greenwood, C.M.T.; Beitel, L.K.; Trifiro, $\mathrm{M}$. New insights into the role of intra-tumor genetic heterogeneity in carcinogenesis: Identification of complex single gene variance within tumors. J. Cancer Metastasis Treat. 2018, 4, 37. [CrossRef]

31. Lee, J.-K.; Choi, Y.-L.; Kwon, M.; Park, P.J. Mechanisms and Consequences of Cancer Genome Instability: Lessons from Genome Sequencing Studies. Annu. Rev. Pathol. Mech. Dis. 2016, 11, 283-312. [CrossRef] [PubMed]

32. Qin, H.; Niu, T.; Zhao, J. Identifying multi-omics causers and causal pathways for complex traits. Front. Genet. 2019, 10. [CrossRef] [PubMed]

33. Kiernan, U.A. Biomarker rediscovery in diagnostics. Expert Opin. Med. Diagn. 2008, 2, 1391-1400. [CrossRef] [PubMed]

34. Shruthi, B.; Vinodhkumar, P.; Selvamani, M. Proteomics: A new perspective for cancer. Adv. Biomed. Res. 2016, 5, 67. [CrossRef] [PubMed]

35. Engin, H.B.; Kreisberg, J.F.; Carter, H. Structure-Based analysis reveals cancer missense mutations target protein interaction interfaces. PLoS ONE 2016, 11. [CrossRef]

36. Vuong, H.; Cheng, F.; Lin, C.C.; Zhao, Z. Functional consequences of somatic mutations in cancer using protein pocket-based prioritization approach. Genome Med. 2014, 6. [CrossRef]

37. Jimenez, C.R.; Zhang, H.; Kinsinger, C.R.; Nice, E.C. The cancer proteomic landscape and the HUPO Cancer Proteome Project. Clin. Proteom. 2018, 15, 4. [CrossRef]

38. Bhawe, K.M.; Aghi, M.K. Microarray analysis in glioblastomas. Methods Mol. Biol. 2016, 1375, 195-206. [CrossRef]

39. Yang, J.X.; Rastetter, R.H.; Wilhelm, D. Non-coding RNAs: An introduction. In Advances in Experimental Medicine and Biology; Springer: New York, NY, USA, 2016; Volume 886, pp. 13-32.

40. Scott, M.S.; Ono, M. From snoRNA to miRNA: Dual function regulatory non-coding RNAs. Biochimie 2011, 93, 1987-1992. [CrossRef]

41. Krumlauf, R. Analysis of gene expression by Northern blot. Mol. Biotechnol. 1994, 2, 227-242. [CrossRef]

42. Goldsworthy, S.M.; Goldsworthy, T.L.; Sprankle, C.S.; Butterworth, B.E. Variation in expression of genes used for normalization of Northern blots after induction of cell proliferation. Cell Prolif. 1993, 26, 511-517. [CrossRef] [PubMed]

43. Moustafa, K.; Cross, J.M. Genetic approaches to study plant responses to environmental stresses: An overview. Biology 2016, 5, 20. [CrossRef] [PubMed]

44. Kolodziejczyk, A.A.; Lönnberg, T. Global and targeted approaches to single-cell transcriptome characterization. Brief. Funct. Genomics 2018, 17, 209-219. [CrossRef] [PubMed]

45. Hager, J. [7] Making and Using Spotted DNA Microarrays in an Academic Core Laboratory. Methods Enzymol. 2006, 410, 135-168. [PubMed]

46. Rifkin, R.; Mukherjee, S.; Tamayo, P.; Ramaswamy, S.; Yeang, C.-H.; Angelo, M.; Reich, M.; Poggio, T.; Lander, E.S.; Todd, T.R.; et al. An analytical method for multiclass molecular Cancer classification. SIAM Rev. 2003, 45, 706-723. [CrossRef]

47. Afzal, M.; Manzoor, I.; Kuipers, O.P. A fast and reliable pipeline for bacterial transcriptome analysis case study: Serine-dependent gene regulation in Streptococcus pneumoniae. J. Vis. Exp. 2015, e52649. [CrossRef] [PubMed]

48. Bumgarner, R. Overview of DNA microarrays: Types, applications, and their future. Curr. Protoc. Mol. Biol. 2013, 101, 22.1.1-22.1.11. [CrossRef]

49. Hryciuk, B.; Szymanowski, B.; Bieńkowski, M.; Perdyan, A.; Korwat, A.; Winnik, K.; Radecka, B.; Żok, J.; Cichowska, N.; Sosińska-Mielcarek, K.; et al. Consistency in biomarkers expression between matched tissue microarray cores from primary gallblader and ovarian cancers. Oncol. Clin. Pract. 2019, 15, 85-88. [CrossRef]

50. Kothapalli, R.; Yoder, S.J.; Mane, S.; Loughran, T.P. Microarray result: How accurate are they? BMC Bioinform. 2002, 3, 22. [CrossRef]

51. Pfeifer, J.D. Molecular Genetic Testing in Surgical Pathology; Lippincott Williams \& Wilkins: Philadelphia, PA, USA, 2006; ISBN 0781747481.

52. Wang, Y.; Barbacioru, C.; Hyland, F.; Xiao, W.; Hunkapiller, K.L.; Blake, J.; Chan, F.; Gonzalez, C.; Zhang, L.; Samaha, R.R. Large scale real-time PCR validation on gene expression measurements from two commercial long-oligonucleotide microarrays. $B M C$ Genom. 2006, 7, 59. [CrossRef]

53. Mocellin, S.; Rossi, C.R.; Pilati, P.; Nitti, D.; Marincola, F.M. Quantitative real-time PCR: A powerful ally in cancer research. Trends Mol. Med. 2003, 9, 189-195. [CrossRef]

54. Monsalve-Lancheros, A.; Ibáñez-Pinilla, M.; Ramírez-Clavijo, S. Detection of mammagloblin by RT-PCR as a biomarker for lymph node metastasis in breast cancer patients: A systematic review and meta-analysis. PLoS ONE 2019, 14, e0216989. [CrossRef] [PubMed] 
55. Lim, S.Y.; Lee, J.H.; Diefenbach, R.J.; Kefford, R.F.; Rizos, H. Liquid biomarkers in melanoma: Detection and discovery. Mol. Cancer 2018, 17, 1-14. [CrossRef] [PubMed]

56. Tanaka, R.; Koyanagi, K.; Narita, N.; Kuo, C.; Hoon, D.S.B. Prognostic molecular biomarkers for cutaneous malignant melanoma. J. Surg. Oncol. 2011, 104, 438-446. [CrossRef]

57. Abdel-Hafiz, S.M.; Hamdy, H.E.M.; Khorshed, F.M.; Aboushousha, T.S.; Safwat, G.; Saber, M.A.; Seleem, M.; Soliman, A.H. Evaluation of osteopontin as a biomarker in Hepatocellular carcinomas in Egyptian patients with chronic HCV cirrhosis. Asian Pacific J. Cancer Prev. 2018, 19, 1021-1027. [CrossRef]

58. Hass, H.G.; Hass, H.; Jobst, J.; Scheurlen, M.; Vogel, U.; Nehls, O. Gene expression analysis for evaluation of potential biomarkers in hepatocellular carcinoma. Anticancer Res. 2015, 35, 2021-2028.

59. Mitas, M.; Mikhitarian, K.; Walters, C.; Baron, P.L.; Elliott, B.M.; Brothers, T.E.; Robison, J.G.; Metcalf, J.S.; Palesch, Y.Y.; Zhang, Z.; et al. Quantitative real-time RT-PCR detection of breast cancer micrometastasis using a multigene marker panel. Int. J. Cancer 2001, 93, 162-171. [CrossRef]

60. Guo, M.; Li, X.; Zhang, S.; Song, H.; Zhang, W.; Shang, X.; Zheng, Y.; Jiang, H.; Lv, Q.; Jiang, Y.; et al. Real-time quantitative RT-PCR detection of circulating tumor cells from breast cancer patients. Int. J. Oncol. 2015, 46, 281-289. [CrossRef]

61. Zebisch, M.; Kölbl, A.C.; Schindlbeck, C.; Neugebauer, J.; Heublein, S.; Ilmer, M.; Rack, B.; Friese, K.; Jeschke, U.; Andergassen, U. Quantification of breast cancer cells in peripheral blood samples by real-time rt-PCR. Anticancer Res. 2012, 32, 5387-5391.

62. Kukurba, K.R.; Montgomery, S.B. RNA sequencing and analysis. Cold Spring Harb. Protoc. 2015, 2015, 951-969. [CrossRef]

63. Sanger, F.; Coulson, A.R. A rapid method for determining sequences in DNA by primed synthesis with DNA polymerase. J. Mol. Biol. 1975, 94. [CrossRef]

64. Kieleczawa, J. Fundamentals of sequencing of difficult templates-An overview. J. Biomol. Tech. 2006, 17, 207-217. [PubMed]

65. Matin, F.; Jeet, V.; Moya, L.; Selth, L.A.; Chambers, S.; Clements, J.A.; Batra, J.; Yeadon, T.; Saunders, P.; Eckert, A.; et al. A plasma biomarker panel of four microRNAs for the diagnosis of prostate cancer. Sci. Rep. 2018, 8, 6653. [CrossRef] [PubMed]

66. Hough, C.D.; Sherman-Baust, C.A.; Pizer, E.S.; Montz, F.J.; Im, D.D.; Rosenshein, N.B.; Cho, K.R.; Riggins, G.J.; Morin, P.J. Large-scale serial analysis of gene expression reveals genes differentially expressed in ovarian cancer. Cancer Res. 2000,60, 6281-6287. [PubMed]

67. Abba, M.C.; Drake, J.A.; Hawkins, K.A.; Hu, Y.; Sun, H.; Notcovich, C.; Gaddis, S.; Sahin, A.; Baggerly, K.; Aldaz, C.M. Transcriptomic changes in human breast cancer progression as determined by serial analysis of gene expression. Breast Cancer Res. 2004, 6, R499-R513. [CrossRef] [PubMed]

68. Campagne, F.; Skrabanek, L. Mining expressed sequence tags identifies cancer markers of clinical interest. BMC Bioinform. 2006, 7, 481. [CrossRef] [PubMed]

69. Heather, J.M.; Chain, B. The sequence of sequencers: The history of sequencing DNA. Genomics 2016, 107, 1-8. [CrossRef] [PubMed]

70. Xie, C.; Tammi, M.T. CNV-seq, a new method to detect copy number variation using high-throughput sequencing. BMC Bioinform. 2009, 10, 80. [CrossRef]

71. Sultan, M.; Schulz, M.H.; Richard, H.; Magen, A.; Klingenhoff, A.; Scherf, M.; Seifert, M.; Borodina, T.; Soldatov, A.; Parkhomchuk, D.; et al. A global view of gene activity and alternative splicing by deep sequencing of the human transcriptome. Science 2008, 321, 956-960. [CrossRef]

72. Lee, C.-Y.; Chiu, Y.-C.; Wang, L.-B.; Kuo, Y.-L.; Chuang, E.Y.; Lai, L.-C.; Tsai, M.-H. Common applications of next-generation sequencing technologies in genomic research. Transl. Cancer Res. 2013, 2, 33-45. [CrossRef]

73. Git, A.; Dvinge, H.; Salmon-Divon, M.; Osborne, M.; Kutter, C.; Hadfield, J.; Bertone, P.; Caldas, C. Systematic comparison of microarray profiling, real-time PCR, and next-generation sequencing technologies for measuring differential microRNA expression. RNA 2010, 16, 991-1006. [CrossRef] [PubMed]

74. Mutz, K.O.; Heilkenbrinker, A.; Lönne, M.; Walter, J.G.; Stahl, F. Transcriptome analysis using next-generation sequencing. Curr. Opin. Biotechnol. 2013, 24, 22-30. [CrossRef] [PubMed]

75. Dudley, D.M.; Chin, E.N.; Bimber, B.N.; Sanabani, S.S.; Tarosso, L.F.; Costa, P.R.; Sauer, M.M.; Kallas, E.G.; O'Connor, D.H. Low-cost ultra-wide genotyping using roche/454 pyrosequencing for surveillance of HIV drug resistance. PLoS ONE 2012, 7, e36494. [CrossRef] [PubMed]

76. Chikamatsu, K.; Aono, A.; Hata, H.; Igarashi, Y.; Takaki, A.; Yamada, H.; Sakashita, K.; Mitarai, S. Evaluation of PyroMark Q24 pyrosequencing as a method for the identification of mycobacteria. Diagn. Microbiol. Infect. Dis. 2018, 90, 35-39. [CrossRef] [PubMed]

77. Del Vecchio, F.; Mastroiaco, V.; Di Marco, A.; Compagnoni, C.; Capece, D.; Zazzeroni, F.; Capalbo, C.; Alesse, E.; Tessitore, A. Next-generation sequencing: Recent applications to the analysis of colorectal cancer. J. Transl. Med. 2017, 15, 246. [CrossRef]

78. Claesson, M.J.; Wang, Q.; O'Sullivan, O.; Greene-Diniz, R.; Cole, J.R.; Ross, R.P.; O'Toole, P.W. Comparison of two next-generation sequencing technologies for resolving highly complex microbiota composition using tandem variable 16S rRNA gene regions. Nucleic Acids Res. 2010, 38, e200. [CrossRef]

79. Loman, N.J.; Misra, R.V.; Dallman, T.J.; Constantinidou, C.; Gharbia, S.E.; Wain, J.; Pallen, M.J. Performance comparison of benchtop high-throughput sequencing platforms. Nat. Biotechnol. 2012, 30, 434-439. [CrossRef]

80. Clarke, P.A.; te Poele, R.; Workman, P. Gene expression microarray technologies in the development of new therapeutic agents. Eur. J. Cancer 2004, 40, 2560-2591. [CrossRef] 
81. Salem, H.; Attiya, G.; El-Fishawy, N. Classification of human cancer diseases by gene expression profiles. Appl. Soft Comput. J. 2017, 50, 124-134. [CrossRef]

82. Golub, T.R.; Slonim, D.K.; Tamayo, P.; Huard, C.; Gaasenbeek, M.; Mesirov, J.P.; Coller, H.; Loh, M.L.; Downing, J.R.; Caligiuri, M.A.; et al. Molecular classification of cancer: Class discovery and class prediction by gene expression monitoring. Science 1999, 286, 531-537. [CrossRef]

83. Gruvberger, S.; Ringnér, M.; Chen, Y.; Panavally, S.; Saal, L.H.; Borg, A.; Fernö, M.; Peterson, C.; Meltzer, P.S. Estrogen receptor status in breast cancer is associated with remarkably distinct gene expression patterns. Cancer Res. 2001, 61, 5979-5984. [PubMed]

84. Stebbing, J.; Wasan, H.S. Decoding metastatic colorectal cancer to improve clinical decision making. J. Clin. Oncol. 2019, 37, 1847-1850. [CrossRef] [PubMed]

85. Sandhu, R.; Parker, J.S.; Jones, W.D.; Livasy, C.A.; Coleman, W.B. Microarray-Based Gene Expression Profiling for Molecular Classification of Breast Cancer and Identification of New Targets for Therapy. Lab. Med. 2010, 41, 364-372. [CrossRef]

86. Reis-Filho, J.S.; Pusztai, L. Gene expression profiling in breast cancer: Classification, prognostication, and prediction. Lancet 2011, 378, 1812-1823. [CrossRef]

87. Perou, C.M.; Sørile, T.; Eisen, M.B.; Van De Rijn, M.; Jeffrey, S.S.; Ress, C.A.; Pollack, J.R.; Ross, D.T.; Johnsen, H.; Akslen, L.A.; et al. Molecular portraits of human breast tumours. Nature 2000, 406, 747-752. [CrossRef]

88. Chand, P.; Anubha, G.; Singla, V.; Rani, N. Evaluation of immunohistochemical profile of breast cancer for prognostics and therapeutic use. Niger. J. Surg. 2018, 24, 100. [CrossRef]

89. Rouzier, R.; Perou, C.M.; Symmans, W.F.; Ibrahim, N.; Cristofanilli, M.; Anderson, K.; Hess, K.R.; Stec, J.; Ayers, M.; Wagner, P.; et al. Breast cancer molecular subtypes respond differently to preoperative chemotherapy. Clin. Cancer Res. 2005, 11, 5678-5685. [CrossRef]

90. Lundberg, A.; Lindström, L.S.; Harrell, J.C.; Falato, C.; Carlson, J.W.; Wright, P.K.; Foukakis, T.; Perou, C.M.; Czene, K.; Bergh, J.; et al. Personalized medicine and imaging gene expression signatures and immunohistochemical subtypes add prognostic value to each other in breast cancer cohorts. Clin. Cancer Res. 2017, 23, 7512-7520. [CrossRef]

91. Sørlie, T.; Perou, C.M.; Tibshirani, R.; Aas, T.; Geisler, S.; Johnsen, H.; Hastie, T.; Eisen, M.B.; Van De Rijn, M.; Jeffrey, S.S.; et al. Gene expression patterns of breast carcinomas distinguish tumor subclasses with clinical implications. Proc. Natl. Acad. Sci. USA 2001, 98, 10869-10874. [CrossRef]

92. Kondov, B.; Milenkovikj, Z.; Kondov, G.; Petrushevska, G.; Basheska, N.; Bogdanovska-Todorovska, M.; Tolevska, N.; Ivkovski, L. Presentation of the molecular subtypes of breast cancer detected by immunohistochemistry in surgically treated patients. Open Access Maced. J. Med. Sci. 2018, 6, 961-967. [CrossRef]

93. Loi, S.; Haibe-Kains, B.; Desmedt, C.; Lallemand, F.; Tutt, A.M.; Gillet, C.; Ellis, P.; Harris, A.; Bergh, J.; Foekens, J.A.; et al. Definition of clinically distinct molecular subtypes in estrogen receptor-positive breast carcinomas through genomic grade. J. Clin. Oncol. 2007, 25, 1239-1246. [CrossRef] [PubMed]

94. Tsang, J.Y.S.; Tse, G.M. Molecular Classification of Breast Cancer. Adv. Anat. Pathol. 2020, 27, 27-35. [CrossRef] [PubMed]

95. Guinney, J.; Dienstmann, R.; Wang, X.; De Reyniès, A.; Schlicker, A.; Soneson, C.; Marisa, L.; Roepman, P.; Nyamundanda, G.; Angelino, P.; et al. The consensus molecular subtypes of colorectal cancer. Nat. Med. 2015, 21, 1350-1356. [CrossRef] [PubMed]

96. Marisa, L.; Ayadi, M.; Balogoun, R.; Pilati, C.; Le Malicot, K.; Lepage, C.; Emile, J.-F.; Salazar, R.; Aust, D.E.; Duval, A.; et al. Clinical utility of colon cancer molecular subtypes: Validation of two main colorectal molecular classifications on the PETACC-8 phase III trial cohort. J. Clin. Oncol. 2017, 35, 3509. [CrossRef]

97. Okita, A.; Takahashi, S.; Ouchi, K.; Inoue, M.; Watanabe, M.; Endo, M.; Honda, H.; Yamada, Y.; Ishioka, C. Consensus molecular subtypes classification of colorectal cancer as a predictive factor for chemotherapeutic efficacy against metastatic colorectal cancer. Oncotarget 2018, 9, 18698-18711. [CrossRef]

98. Lenz, H.-J.; Ou, F.-S.; Venook, A.P.; Hochster, H.S.; Niedzwiecki, D.; Goldberg, R.M.; Mayer, R.J.; Bertagnolli, M.M.; Blanke, C.D.; Zemla, T.; et al. Impact of consensus molecular subtyping (CMS) on overall survival (OS) and progression free survival (PFS) in patients (pts) with metastatic colorectal cancer (mCRC): Analysis of CALGB/SWOG 80405 (Alliance). J. Clin. Oncol. 2017, 35, 3511. [CrossRef]

99. Stintzing, S.; Wirapati, P.; Lenz, H.-J.; Neureiter, D.; Fischer von Weikersthal, L.; Decker, T.; Kiani, A.; Vehling-Kaiser, U.; Al-Batran, S.-E.; Heintges, T.; et al. Consensus molecular subgroups (CMS) of colorectal cancer (CRC) and first-line efficacy of FOLFIRI plus cetuximab or bevacizumab in the FIRE3 (AIO KRK-0306) trial. J. Clin. Oncol. 2017, 35, 3510. [CrossRef]

100. Mooi, J.K.; Wirapati, P.; Asher, R.; Lee, C.K.; Savas, P.; Price, T.J.; Townsend, A.; Hardingham, J.; Buchanan, D.; Williams, D.; et al The prognostic impact of consensus molecular subtypes (CMS) and its predictive effects for bevacizumab benefit in metastatic colorectal cancer: Molecular analysis of the AGITG MAX clinical trial. Ann. Oncol. 2018, 29, 2240-2246. [CrossRef]

101. Fontana, E.; Eason, K.; Cervantes, A.; Salazar, R.; Sadanandam, A. Context matters-consensus molecular subtypes of colorectal cancer as biomarkers for clinical trials. Ann. Oncol. 2019, 30, 520-527. [CrossRef]

102. Peres, L.C.; Cushing-Haugen, K.L.; Anglesio, M.; Wicklund, K.; Bentley, R.; Berchuck, A.; Kelemen, L.E.; Nazeran, T.M.; Gilks, C.B.; Harris, H.R.; et al. Histotype classification of ovarian carcinoma: A comparison of approaches. Gynecol. Oncol. 2018, 151, 53-60. [CrossRef]

103. Labidi-Galy, S.I.; Papp, E.; Hallberg, D.; Niknafs, N.; Adleff, V.; Noe, M.; Bhattacharya, R.; Novak, M.; Jones, S.; Phallen, J.; et al. High grade serous ovarian carcinomas originate in the fallopian tube. Nat. Commun. 2017, 8, 1093. [CrossRef] [PubMed] 
104. Wang, J.; Dean, D.C.; Hornicek, F.J.; Shi, H.; Duan, Z. RNA sequencing (RNA-Seq) and its application in ovarian cancer. Gynecol. Oncol. 2019, 152, 194-201. [CrossRef] [PubMed]

105. Li, X.; Beihua, K. PAX8 is a novel marker for differentiating between various types of tumor, particularly ovarian epithelial carcinomas. Oncol. Lett. 2013, 5, 735-738.

106. Rodgers, L.H.; hAinmhire, E.Ó.; Young, A.N.; Burdette, J.E. Loss of PAX8 in high-grade serous ovarian cancer reduces cell survival despite unique modes of action in the fallopian tube and ovarian surface epithelium. Oncotarget 2016, 7, 32785-32795. [CrossRef] [PubMed]

107. Tschentscher, F.; Hüsing, J.; Hölter, T.; Kruse, E.; Dresen, I.G.; Jöckel, K.-H.; Anastassiou, G.; Schilling, H.; Bornfeld, N.; Horsthemke, B.; et al. Tumor Classification Based on Gene Expression Profiling Shows That Uveal Melanomas with and without Monosomy 3 Represent Two Distinct Entities. Cancer Res. 2003, 63, 2578-2584.

108. Khan, J.; Wei, J.S.; Ringnér, M.; Saal, L.H.; Ladanyi, M.; Westermann, F.; Berthold, F.; Schwab, M.; Antonescu, C.R.; Peterson, C.; et al. Classification and diagnostic prediction of cancers using gene expression profiling and artificial neural networks. Nat. Med. 2001, 7, 673-679. [CrossRef]

109. Karlsson, A.; Brunnström, H.; Micke, P.; Veerla, S.; Mattsson, J.; La Fleur, L.; Botling, J.; Jönsson, M.; Reuterswärd, C.; Planck, M.; et al. Gene Expression Profiling of Large Cell Lung Cancer Links Transcriptional Phenotypes to the New Histological WHO 2015 Classification. J. Thorac. Oncol. 2017, 12, 1257-1267. [CrossRef]

110. Zivicova, V.; Gal, P.; Mifkova, A.; Novak, S.; Kaltner, H.; Kolar, M.; Strnad, H.; Sachova, J.; Hradilova, M.; Chovanec, M.; et al. Detection of Distinct Changes in Gene-expression Profiles in Specimens of Tumors and Transition Zones of Tenascin-positive/negative Head and Neck Squamous Cell Carcinoma. Anticancer Res. 2018, 38, 1279-1290. [CrossRef]

111. Lin, X.; Zhao, Y.; Song, W.M.; Zhang, B. Molecular classification and prediction in gastric cancer. Comput. Struct. Biotechnol. J. 2015, 13, 448-458. [CrossRef]

112. Park, J.; Shim, J.K.; Yoon, S.J.; Kim, S.H.; Chang, J.H.; Kang, S.G. Transcriptome profiling-based identification of prognostic subtypes and multi-omics signatures of glioblastoma. Sci. Rep. 2019, 9, 1-11. [CrossRef]

113. Phillips, H.S.; Kharbanda, S.; Chen, R.; Forrest, W.F.; Soriano, R.H.; Wu, T.D.; Misra, A.; Nigro, J.M.; Colman, H.; Soroceanu, L.; et al. Molecular subclasses of high-grade glioma predict prognosis, delineate a pattern of disease progression, and resemble stages in neurogenesis. Cancer Cell 2006, 9, 157-173. [CrossRef] [PubMed]

114. Elias, K.M.; Guo, J.; Bast, R.C. Early Detection of Ovarian Cancer. Hematol. Oncol. Clin. N. Am. 2018, 32, 903-914. [CrossRef] [PubMed]

115. Pepin, K.; Del Carmen, M.; Brown, A.; Dizon, D.S. CA 125 and epithelial ovarian cancer: Role in screening, diagnosis and Surveillance. Am. J. Hematol. Oncol. 2014, 10, 22-29.

116. Moss, E.L.; Hollingworth, J.; Reynolds, T.M. The role of CA125 in clinical practice. J. Clin. Pathol. 2005, 58, 308-312. [CrossRef] [PubMed]

117. Mosig, R.A.; Lobl, M.; Senturk, E.; Shah, H.; Cohen, S.; Chudin, E.; Fruscio, R.; Marchini, S.; D’Incalci, M.; Sachidanandam, R.; et al. IGFBP-4 tumor and serum levels are increased across all stages of epithelial ovarian cancer. J. Ovarian Res. 2012, 5, 3. [CrossRef]

118. Nassri, A.; Zhu, H.; Muftah, M.; Ramzan, Z. Epidemiology and Survival of Esophageal Cancer Patients in an American Cohort. Cureus 2018, 10. [CrossRef]

119. Yang, Y.; Huang, X.; Zhou, L.; Deng, T.; Ning, T.; Liu, R.; Zhang, L.; Bai, M.; Zhang, H.; Li, H.; et al. Clinical use of tumor biomarkers in prediction for prognosis and chemotherapeutic effect in esophageal squamous cell carcinoma. BMC Cancer 2019, 19, 526. [CrossRef]

120. Zheng, X.; Xing, S.; Liu, X.M.; Liu, W.; Liu, D.; Chi, P.D.; Chen, H.; Dai, S.Q.; Zhong, Q.; Zeng, M.S.; et al. Establishment of using serum YKL-40 and SCCA in combination for the diagnosis of patients with esophageal squamous cell carcinoma. BMC Cancer 2014, 14, 490. [CrossRef]

121. Shi, L.; Westerhuis, J.A.; Rosén, J.; Landberg, R.; Brunius, C. Variable selection and validation in multivariate modelling. Bioinformatics 2019, 35, 972-980. [CrossRef]

122. Kumar, D.; Bansal, G.; Narang, A.; Basak, T.; Abbas, T.; Dash, D. Integrating transcriptome and proteome profiling: Strategies and applications. Proteomics 2016, 16, 2533-2544. [CrossRef]

123. Baumgartner, C.; Osl, M.; Netzer, M.; Baumgartner, D. Bioinformatic-driven search for metabolic biomarkers in disease. J. Clin. Bioinform. 2011, 1, 2. [CrossRef] [PubMed]

124. Hira, Z.M.; Gillies, D.F. A review of feature selection and feature extraction methods applied on microarray data. Adv. Bioinform. 2015, 2015. [CrossRef] [PubMed]

125. Eide, P.W.; Bruun, J.; Lothe, R.A.; Sveen, A. CMScaller: An R package for consensus molecular subtyping of colorectal cancer pre-clinical models. Sci. Rep. 2017, 7, 16618. [CrossRef] [PubMed]

126. Colombo, C.; Minna, E.; Gargiuli, C.; Muzza, M.; Dugo, M.; De Cecco, L.; Pogliaghi, G.; Tosi, D.; Bulfamante, G.; Greco, A.; et al. The molecular and gene/miRNA expression profiles of radioiodine resistant papillary thyroid cancer. J. Exp. Clin. Cancer Res. 2020, 39. [CrossRef]

127. Tsagris, M.; Tsamardinos, I. Feature selection with the R package MXM. F1000Research 2018, 7, 1505. [CrossRef] [PubMed] 
128. Xing, S.; Zheng, X.; Wei, L.Q.; Song, S.J.; Liu, D.; Xue, N.; Liu, X.M.; Wu, M.T.; Zhong, Q.; Huang, C.M.; et al. Development and validation of a serum biomarker panel for the detection of esophageal squamous cell carcinoma through RNA transcriptome sequencing. J. Cancer 2017, 8, 2346-2355. [CrossRef]

129. Xi, X.; Li, T.; Huang, Y.; Sun, J.; Zhu, Y.; Yang, Y.; Lu, Z.J. RNA biomarkers: Frontier of precision medicine for cancer. Non-coding RNA 2017, 3, 9. [CrossRef]

130. Liao, J.; Yu, L.; Mei, Y.; Guarnera, M.; Shen, J.; Li, R.; Liu, Z.; Jiang, F. Small nucleolar RNA signatures as biomarkers for non-small-cell lung cancer. Mol. Cancer 2010, 9, 198. [CrossRef]

131. Nadal, E.; Truini, A.; Nakata, A.; Lin, J.; Reddy, R.M.; Chang, A.C.; Ramnath, N.; Gotoh, N.; Beer, D.G.; Chen, G. A novel serum 4-microRNA signature for lung cancer detection. Sci. Rep. 2015, 5, 12464. [CrossRef]

132. Cai, H.; Yuan, Y.; Hao, Y.F.; Guo, T.K.; Wei, X.; Zhang, Y.M. Plasma microRNAs serve as novel potential biomarkers for early detection of gastric cancer. Med. Oncol. 2013, 30, 452. [CrossRef]

133. Toiyama, Y.; Okugawa, Y.; Goel, A. DNA methylation and microRNA biomarkers for noninvasive detection of gastric and colorectal cancer. Biochem. Biophys. Res. Commun. 2014, 455, 43-57. [CrossRef] [PubMed]

134. Busch, J.; Ralla, B.; Jung, M.; Wotschofsky, Z.; Trujillo-Arribas, E.; Schwabe, P.; Kilic, E.; Fendler, A.; Jung, K. Piwi-interacting RNAs as novel prognostic markers in clear cell renal cell carcinomas. J. Exp. Clin. Cancer Res. 2015, 34, 61. [CrossRef] [PubMed]

135. Li, Y.; Wu, X.; Gao, H.; Jin, J.M.; Li, A.X.; Kim, Y.S.; Pal, S.K.; Nelson, R.A.; Lau, C.M.; Guo, C.; et al. Piwi-interacting RNAs (piRNAs) are dysregulated in renal cell carcinoma and associated with tumor metastasis and cancer-specific survival. Mol. Med. 2015, 21, 381-388. [CrossRef] [PubMed]

136. Rizzo, F.; Rinaldi, A.; Marchese, G.; Coviello, E.; Sellitto, A.; Cordella, A.; Giurato, G.; Nassa, G.; Ravo, M.; Tarallo, R.; et al. Specific patterns of PIWI-interacting small noncoding RNA expression in dysplastic liver nodules and hepatocellular carcinoma. Oncotarget 2016, 7, 54650-54661. [CrossRef]

137. Liu, Y.; Dou, M.; Song, X.; Dong, Y.; Liu, S.; Liu, H.; Tao, J.; Li, W.; Yin, X.; Xu, W. The emerging role of the piRNA/piwi complex in cancer. Mol. Cancer 2019, 18,1-15. [CrossRef]

138. Cui, L.; Lou, Y.; Zhang, X.; Zhou, H.; Deng, H.; Song, H.; Yu, X.; Xiao, B.; Wang, W.; Guo, J. Detection of circulating tumor cells in peripheral blood from patients with gastric cancer using piRNAs as markers. Clin. Biochem. 2011, 44, 1050-1057. [CrossRef]

139. Lu, Q.; Yu, T.; Ou, X.; Cao, D.; Xie, T.; Chen, X. Potential lncRNA diagnostic biomarkers for early gastric cancer. Mol. Med. Rep. 2017, 16, 9545-9552. [CrossRef]

140. Vychytilova-Faltejskova, P.; Stitkovcova, K.; Radova, L.; Sachlova, M.; Kosarova, Z.; Slaba, K.; Kala, Z.; Svoboda, M.; Kiss, I.; Vyzula, R.; et al. Circulating PIWI-interacting RNAs piR-5937 and piR-28876 are promising diagnostic biomarkers of colon cancer. Cancer Epidemiol. Biomark. Prev. 2018, 27, 1019-1028. [CrossRef]

141. Slaby, O. Non-coding RNAs as biomarkers for colorectal cancer screening and early detection. Adv. Exp. Med. Biol. 2016, 937, 153-170. [CrossRef]

142. Kahraman, M.; Röske, A.; Laufer, T.; Fehlmann, T.; Backes, C.; Kern, F.; Kohlhaas, J.; Schrörs, H.; Saiz, A.; Zabler, C.; et al. MicroRNA in diagnosis and therapy monitoring of early-stage triple-negative breast cancer. Sci. Rep. 2018, 8, 1-11. [CrossRef]

143. Liu, H.; Li, J.; Koirala, P.; Ding, X.; Chen, B.; Wang, Y.; Wang, Z.; Wang, C.; Zhang, X.; Mo, Y.Y. Long non-coding RNAs as prognostic markers in human breast cancer. Oncotarget 2016, 7, 20584-20596. [CrossRef] [PubMed]

144. Yu, T.; Zhang, H.; Qi, H. Transcriptome profiling analysis reveals biomarkers in colon cancer samples of various differentiation. Oncol. Lett. 2018, 16, 48-54. [CrossRef] [PubMed]

145. Koga, Y.; Yasunaga, M.; Takahashi, A.; Kuroda, J.; Moriya, Y.; Akasu, T.; Fujita, S.; Yamamoto, S.; Baba, H.; Matsumura, Y. MicroRNA expression profiling of exfoliated colonocytes isolated from feces for colorectal cancer screening. Cancer Prev. Res. 2010, 3, 1435-1442. [CrossRef] [PubMed]

146. Gu, X.; Li, B.; Jiang, M.; Fang, M.; Ji, J.; Wang, A.; Wang, M.; Jiang, X.; Gao, C. RNA sequencing reveals differentially expressed genes as potential diagnostic and prognostic indicators of gallbladder carcinoma. Oncotarget 2015, 6, 20661-20671. [CrossRef]

147. Tsujiura, M.; Ichikawa, D.; Komatsu, S.; Shiozaki, A.; Takeshita, H.; Kosuga, T.; Konishi, H.; Morimura, R.; Deguchi, K.; Fujiwara, H.; et al. Circulating microRNAs in plasma of patients with gastric cancers. Br. J. Cancer 2010, 102, 1174-1179. [CrossRef]

148. Liu, R.; Zhang, C.; Hu, Z.; Li, G.; Wang, C.; Yang, C.; Huang, D.; Chen, X.; Zhang, H.; Zhuang, R.; et al. A five-microRNA signature identified from genome-wide serum microRNA expression profiling serves as a fingerprint for gastric cancer diagnosis. Eur. J. Cancer 2011, 47, 784-791. [CrossRef]

149. Cheng, Q.; Li, J.; Fan, F.; Cao, H.; Dai, Z.Y.; Wang, Z.Y.; Feng, S.S. Identification and Analysis of Glioblastoma Biomarkers Based on Single Cell Sequencing. Front. Bioeng. Biotechnol. 2020, 8, 167. [CrossRef]

150. Huang, S.W.; Ali, N.-d.; Zhong, L.; Shi, J. MicroRNAs as biomarkers for human glioblastoma: Progress and potential. Acta Pharmacol. Sin. 2018, 39, 1405-1413. [CrossRef]

151. Cordeiro, A.; Navarro, A.; Gaya, A.; Díaz-Beyá, M.; Gonzalez-Farré, B.; Castellano, J.J.; Fuster, D.; Martínez, C.; Martínez, A.; Monzó, M. PiwiRNA-651 as marker of treatment response and survival in classical Hodgkin lymphoma. Oncotarget 2016, 7 , 46002-46013. [CrossRef]

152. Solé, C.; Tramonti, D.; Schramm, M.; Goicoechea, I.; Armesto, M.; Hernandez, L.I.; Manterola, L.; Fernandez-Mercado, M.; Mujika, K.; Tuneu, A.; et al. The circulating transcriptome as a source of biomarkers for melanoma. Cancers 2019, 11, 70. [CrossRef] 
153. Saldanha, G.; Potter, L.; Shendge, P.; Osborne, J.; Nicholson, S.; Yii, N.; Varma, S.; Aslam, M.I.; Elshaw, S.; Papadogeorgakis, E.; et al. Plasma microRNA-21 is associated with tumor burden in cutaneous melanoma. J. Invest. Dermatol. 2013, 133, 1381-1384. [CrossRef] [PubMed]

154. Li, B.; Hong, J.; Hong, M.; Wang, Y.; Yu, T.; Zang, S.; Wu, Q. piRNA-823 delivered by multiple myeloma-derived extracellular vesicles promoted tumorigenesis through re-educating endothelial cells in the tumor environment. Oncogene 2019, 38, 5227-5238. [CrossRef] [PubMed]

155. Bianchi, F.; Nicassio, F.; Marzi, M.; Belloni, E.; Dall'Olio, V.; Bernard, L.; Pelosi, G.; Maisonneuve, P.; Veronesi, G.; Di Fiore, P.P. A serum circulating miRNA diagnostic test to identify asymptomatic high-risk individuals with early stage lung cancer. $E M B O \mathrm{Mol}$. Med. 2011, 3, 495-503. [CrossRef] [PubMed]

156. Zhang, L.; Farrell, J.J.; Zhou, H.; Elashoff, D.; Akin, D.; Park, N.H.; Chia, D.; Wong, D.T. Salivary Transcriptomic Biomarkers for Detection of Resectable Pancreatic Cancer. Gastroenterology 2010, 138, 949. [CrossRef]

157. Kosanam, H.; Prassas, I.; Chrystoja, C.C.; Soleas, I.; Chan, A.; Dimitromanolakis, A.; Blasutig, I.M.; Rückert, F.; Gruetzmann, R.; Pilarsky, C.; et al. Laminin, gamma 2 (LAMC2): A promising new putative pancreatic cancer biomarker identified by proteomic analysis of pancreatic adenocarcinoma tissues. Mol. Cell. Proteom. 2013, 12, 2820-2832. [CrossRef]

158. Iliev, R.; Stanik, M.; Fedorko, M.; Poprach, A.; Vychytilova-Faltejskova, P.; Slaba, K.; Svoboda, M.; Fabian, P.; Pacik, D.; Dolezel, J.; et al. Decreased expression levels of PIWIL1, PIWIL2, and PIWIL4 are associated with worse survival in renal cell carcinoma patients. Onco. Targets. Ther. 2016, 9, 217-222. [CrossRef]

159. Chian, C.F.; Hwang, Y.T.; Terng, H.J.; Lee, S.C.; Chao, T.Y.; Chang, H.; Ho, C.L.; Wu, Y.Y.; Perng, W.C. Panels of tumor-derived RNA markers in peripheral blood of patients with non-small cell lung cancer: Their dependence on age, gender and clinical stages. Oncotarget 2016, 7, 50582-50595. [CrossRef]

160. Yu, L.; Todd, N.W.; Xing, L.; Xie, Y.; Zhang, H.; Liu, Z.; Fang, H.; Zhang, J.; Katz, R.L.; Jiang, F. Early detection of lung adenocarcinoma in sputum by a panel of microRNA markers. Int. J. Cancer 2010, 127, 2870-2878. [CrossRef]

161. Xie, Y.; Todd, N.W.; Liu, Z.; Zhan, M.; Fang, H.B.; Peng, H.; Alattar, M.; Deepak, J.; Stass, S.A.; Jiang, F. Altered miRNA expression in sputum for diagnosis of non-small cell lung cancer. Lung Cancer 2010, 67, 170-176. [CrossRef]

162. Yu, M.; Stott, S.; Toner, M.; Maheswaran, S.; Haber, D.A. Circulating tumor cells: Approaches to isolation and characterization. J. Cell Biol. 2011, 192, 373-382. [CrossRef]

163. Papadopoulou, E.; Tsoulos, N.; Tsantikidi, K.; Metaxa-Mariatou, V.; Stamou, P.E.; Kladi-Skandali, A.; Kapeni, E.; Tsaousis, G.; Pentheroudakis, G.; Petrakis, D.; et al. Clinical feasibility of NGS liquid biopsy analysis in NSCLC patients. PLoS ONE 2019, 14, e226853. [CrossRef] [PubMed]

164. Johann, D.J.; Steliga, M.; Shin, I.J.; Yoon, D.; Arnaoutakis, K.; Hutchins, L.; Liu, M.; Liem, J.; Walker, K.; Pereira, A.; et al. Liquid biopsy and its role in an advanced clinical trial for lung cancer. Exp. Biol. Med. 2018, 243, 262-271. [CrossRef] [PubMed]

165. Sorber, L.; Zwaenepoel, K.; Deschoolmeester, V.; Van Schil, P.E.Y.; Van Meerbeeck, J.; Lardon, F.; Rolfo, C.; Pauwels, P. Circulating cell-free nucleic acids and platelets as a liquid biopsy in the provision of personalized therapy for lung cancer patients. Lung Cancer 2017, 107, 100-107. [CrossRef] [PubMed]

166. Lu, Y.-T.; Delijani, K.; Mecum, A.; Goldkorn, A. Current status of liquid biopsies for the detection and management of prostate cancer. Cancer Manag. Res. 2019, 11, 5271-5291. [CrossRef] [PubMed]

167. Ozsolak, F.; Milos, P.M. RNA sequencing: Advances, challenges and opportunities. Nat. Rev. Genet. 2011, 12, 87-98. [CrossRef] [PubMed]

168. Watson, P.A.; Arora, V.K.; Sawyers, C.L. Emerging mechanisms of resistance to androgen receptor inhibitors in prostate cancer. Nat. Rev. Cancer 2015, 15, 701-711. [CrossRef]

169. Montani, F.; Marzi, M.J.; Dezi, F.; Dama, E.; Carletti, R.M.; Bonizzi, G.; Bertolotti, R.; Bellomi, M.; Rampinelli, C.; Maisonneuve, P.; et al. MiR-test: A blood test for lung cancer early detection. J. Natl. Cancer Inst. 2015, 107. [CrossRef]

170. Sokoll, L.J.; Ellis, W.; Lange, P.; Noteboom, J.; Elliott, D.J.; Deras, I.L.; Blase, A.; Koo, S.; Sarno, M.; Rittenhouse, H.; et al. A multicenter evaluation of the PCA3 molecular urine test: Pre-analytical effects, analytical performance, and diagnostic accuracy. Clin. Chim. Acta 2008, 389, 1-6. [CrossRef]

171. Van Neste, L.; Hendriks, R.J.; Dijkstra, S.; Trooskens, G.; Cornel, E.B.; Jannink, S.A.; de Jong, H.; Hessels, D.; Smit, F.P.; Melchers, W.J.G.; et al. Detection of High-grade Prostate Cancer Using a Urinary Molecular Biomarker-Based Risk Score. Eur. Urol. 2016, 70, 740-748. [CrossRef]

172. Fernández-Lázaro, D.; Hernández, J.L.G.; García, A.C.; del Castillo, A.C.; Hueso, M.V.; Cruz-Hernández, J.J. Clinical perspective and translational oncology of liquid biopsy. Diagnostics 2020, 10, 443. [CrossRef]

173. Soliman, H.; Shah, V.; Srkalovic, G.; Mahtani, R.; Levine, E.; Mavromatis, B.; Srinivasiah, J.; Kassar, M.; Gabordi, R.; Qamar, R.; et al. MammaPrint guides treatment decisions in breast Cancer: Results of the IMPACt trial. BMC Cancer 2020, 20, 81. [CrossRef] [PubMed]

174. Van De Vijver, M.J.; He, Y.D.; Van'T Veer, L.J.; Dai, H.; Hart, A.A.M.; Voskuil, D.W.; Schreiber, G.J.; Peterse, J.L.; Roberts, C.; Marton, M.J.; et al. A gene-expression signature as a predictor of survival in breast cancer. N. Engl. J. Med. 2002, 347, 1999-2009. [CrossRef] [PubMed]

175. Cardoso, F.; Piccart-Gebhart, M.; Van't Veer, L.; Rutgers, E. The MINDACT trial: The first prospective clinical validation of a genomic tool. Mol. Oncol. 2007, 1, 246-251. [CrossRef] [PubMed] 
176. Nicolini, A.; Ferrari, P.; Duffy, M.J. Prognostic and predictive biomarkers in breast cancer: Past, present and future. Semin. Cancer Biol. 2018, 52, 56-73. [CrossRef]

177. Sparano, J.A.; Gray, R.J.; Makower, D.F.; Pritchard, K.I.; Albain, K.S.; Hayes, D.F.; Geyer, C.E.; Dees, E.C.; Goetz, M.P.; Olson, J.A.; et al. Adjuvant Chemotherapy Guided by a 21-Gene Expression Assay in Breast Cancer. N. Engl. J. Med. 2018, 379, $111-121$. [CrossRef]

178. Wallden, B.; Storhoff, J.; Nielsen, T.; Dowidar, N.; Schaper, C.; Ferree, S.; Liu, S.; Leung, S.; Geiss, G.; Snider, J.; et al. Development and verification of the PAM50-based Prosigna breast cancer gene signature assay. BMC Med. Genom. 2015, 8, 54. [CrossRef]

179. Jensen, M.B.; Lænkholm, A.V.; Nielsen, T.O.; Eriksen, J.O.; Wehn, P.; Hood, T.; Ram, N.; Buckingham, W.; Ferree, S.; Ejlertsen, B. The Prosigna gene expression assay and responsiveness to adjuvant cyclophosphamide-based chemotherapy in premenopausal high-risk patients with breast cancer. Breast Cancer Res. 2018, 20, 79. [CrossRef]

180. Sestak, I.; Martín, M.; Dubsky, P.; Kronenwett, R.; Rojo, F.; Cuzick, J.; Filipits, M.; Ruiz, A.; Gradishar, W.; Soliman, H.; et al. Prediction of chemotherapy benefit by EndoPredict in patients with breast cancer who received adjuvant endocrine therapy plus chemotherapy or endocrine therapy alone. Breast Cancer Res. Treat. 2019, 176, 377-386. [CrossRef]

181. Mokbel, K.; Wazir, U.; Wazir, A.; Kasem, A.; Mokbel, K. The impact of endopredict clinical score on chemotherapy recommendations in women with invasive ER+/HER2-breast cancer stratified as having moderate or poor prognosis by nottingham prognostic index. Anticancer Res. 2018, 38, 4747-4752. [CrossRef]

182. You, Y.N.; Rustin, R.B.; Sullivan, J.D. Oncotype DX ${ }^{\circledR}$ colon cancer assay for prediction of recurrence risk in patients with stage II and III colon cancer: A review of the evidence. Surg. Oncol. 2015, 24, 61-66. [CrossRef]

183. Dawod, M.A.I.; Sui, J.S.Y.; Kelly, D.; McSorley, L.M.; Brady, C.; Bambury, R.; O’Reilly, S.; Andrews, E.J.; McCourt, M.; O’Riordain, M.; et al. Clinical utility of Oncotype DX in early stage colon cancer. J. Clin. Oncol. 2017, 35, e15076. [CrossRef]

184. Govindarajan, R.; Posey, J.; Chao, C.Y.; Lu, R.; Jadhav, T.; Javed, A.Y.; Javed, A.; Mahmoud, F.A.; Osarogiagbon, R.U.; Manne, U. A comparison of 12-gene colon cancer assay gene expression in African American and Caucasian patients with stage II colon cancer. BMC Cancer 2016, 16, 368. [CrossRef] [PubMed]

185. Abdul Aziz, N.A.; Mokhtar, N.M.; Harun, R.; Mollah, M.M.H.; Mohamed Rose, I.; Sagap, I.; Mohd Tamil, A.; Wan Ngah, W.Z.; Jamal, R. A 19-Gene expression signature as a predictor of survival in colorectal cancer. BMC Med. Genom. 2016, 9, 58. [CrossRef] [PubMed]

186. Kloos, R.T.; Nodülü, T.; Profillemesi, M.; Gen, A.; Sınıflandırıcısının, E.; Karar, K.; Üzerinde, V.; Rolü, G. Molecular Profiling of Thyroid Nodules: Current Role for the Afirma Gene Expression Classifier on Clinical Decision Making. Rev. Mol. Imaging Radionucl Ther 2017, 26, 36-49. [CrossRef] [PubMed]

187. Vargas-Salas, S.; Martínez, J.R.; Urra, S.; Domínguez, J.M.; Mena, N.; Uslar, T.; Lagos, M.; Henríquez, M.; González, H.E. Genetic testing for indeterminate thyroid cytology: Review and meta-analysis. Endocr. Relat. Cancer 2018, 25, R163-R177. [CrossRef] [PubMed]

188. González, H.E.; Martínez, J.R.; Vargas-Salas, S.; Solar, A.; Veliz, L.; Cruz, F.; Arias, T.; Loyola, S.; Horvath, E.; Tala, H.; et al. A 10-Gene Classifier for Indeterminate Thyroid Nodules: Development and Multicenter Accuracy Study. Thyroid 2017, 27, 1058-1067. [CrossRef] [PubMed]

189. Nikiforova, M.N.; Mercurio, S.; Wald, A.I.; Barbi de Moura, M.; Callenberg, K.; Santana-Santos, L.; Gooding, W.E.; Yip, L.; Ferris, R.L.; Nikiforov, Y.E. Analytical performance of the ThyroSeq v3 genomic classifier for cancer diagnosis in thyroid nodules. Cancer 2018, 124, 1682-1690. [CrossRef]

190. Dos Santos, M.T.; Buzolin, A.L.; Gama, R.R.; Da Silva, E.C.A.; Dufloth, R.M.; Figueiredo, D.L.A.; Carvalho, A.L. Molecular Classification of Thyroid Nodules with Indeterminate Cytology: Development and Validation of a Highly Sensitive and Specific New miRNA-Based Classifier Test Using Fine-Needle Aspiration Smear Slides. Thyroid 2018, 28, 1618-1626. [CrossRef]

191. Nishino, M.; Nikiforova, M. Update on molecular testing for cytologically indeterminate thyroid nodules. Arch. Pathol. Lab. Med. 2018, 142, 446-457. [CrossRef]

192. Seow, J.J.W.; Wong, R.M.M.; Pai, R.; Sharma, A. Single-Cell RNA Sequencing for Precision Oncology: Current State-of-Art. J. Indian Inst. Sci. 2020, 100, 579-588. [CrossRef]

193. Fan, J.; Lee, H.O.; Lee, S.; Ryu, D.E.; Lee, S.; Xue, C.; Kim, S.J.; Kim, K.; Barkas, N.; Park, P.J.; et al. Linking transcriptional and genetic tumor heterogeneity through allele analysis of single-cell RNA-seq data. Genome Res. 2018, 28, 1217-1227. [CrossRef] [PubMed]

194. Sharma, A.; Merritt, E.; Hu, X.; Cruz, A.; Jiang, C.; Sarkodie, H.; Zhou, Z.; Malhotra, J.; Riedlinger, G.M.; De, S. Non-Genetic Intra-Tumor Heterogeneity Is a Major Predictor of Phenotypic Heterogeneity and Ongoing Evolutionary Dynamics in Lung Tumors. Cell Rep. 2019, 29, 2164-2174.e5. [CrossRef] [PubMed]

195. Wu, S.; Zhang, H.; Fouladdel, S.; Li, H.; Keller, E.; Wicha, M.S.; Omenn, G.S.; Azizi, E.; Guan, Y. Cellular, transcriptomic and isoform heterogeneity of breast cancer cell line revealed by full-length single-cell RNA sequencing. Comput. Struct. Biotechnol. J. 2020, 18, 676-685. [CrossRef] [PubMed]

196. Curtis, M.; Kenny, H.A.; Ashcroft, B.; Mukherjee, A.; Johnson, A.; Zhang, Y.; Helou, Y.; Batlle, R.; Liu, X.; Gutierrez, N.; et al. Fibroblasts Mobilize Tumor Cell Glycogen to Promote Proliferation and Metastasis. Cell Metab. 2019, 29, 141-155.e9. [CrossRef] [PubMed]

197. Xiao, Z.; Dai, Z.; Locasale, J.W. Metabolic landscape of the tumor microenvironment at single cell resolution. Nat. Commun. 2019, 10, 1-12. [CrossRef] 
198. Panichnantakul, P.; Bourgey, M.; Montpetit, A.; Bourque, G.; Riazalhosseini, Y. RNA-seq as a tool to study the tumor microenvironment. Methods Mol. Biol. 2016, 1458, 311-337. [CrossRef]

199. Smith, C.C.; Bixby, L.M.; Miller, K.L.; Selitsky, S.R.; Bortone, D.S.; Hoadley, K.A.; Vincent, B.G.; Serody, J.S. Using RNA Sequencing to Characterize the Tumor Microenvironment. In Methods in Molecular Biology; Humana Press Inc.: Totowa, NJ, USA, 2020; Volume 2055, pp. 245-272.

200. Lau, D.; Bobe, A.M.; Khan, A.A. RNA Sequencing of the Tumor Microenvironment in Precision Cancer Immunotherapy. Trends Cancer 2019, 5, 149-156. [CrossRef]

201. Hopkins, A.C.; Yarchoan, M.; Durham, J.N.; Yusko, E.C.; Rytlewski, J.A.; Robins, H.S.; Laheru, D.A.; Le, D.T.; Lutz, E.R.; Jaffee, E.M. T cell receptor repertoire features associated with survival in immunotherapy-treated pancreatic ductal adenocarcinoma. JCI Insight 2018, 3, 973. [CrossRef]

202. Tumeh, P.C.; Harview, C.L.; Yearley, J.H.; Shintaku, I.P.; Taylor, E.J.M.; Robert, L.; Chmielowski, B.; Spasic, M.; Henry, G.; Ciobanu, V.; et al. PD-1 blockade induces responses by inhibiting adaptive immune resistance. Nature 2014, 515, 568-571. [CrossRef]

203. Hosseinahli, N.; Aghapour, M.; Duijf, P.H.G.; Baradaran, B. Treating cancer with microRNA replacement therapy: A literature review. J. Cell. Physiol. 2018, 233, 5574-5588. [CrossRef]

204. Hemmatzadeh, M.; Mohammadi, H.; Jadidi-Niaragh, F.; Asghari, F.; Yousefi, M. The role of oncomirs in the pathogenesis and treatment of breast cancer. Biomed. Pharmacother. 2016, 78, 129-139. [CrossRef] [PubMed]

205. Garzon, R.; Marcucci, G.; Croce, C.M. Targeting microRNAs in cancer: Rationale, strategies and challenges. Nat. Rev. Drug Discov. 2010, 9, 775-789. [CrossRef] [PubMed]

206. Nedaeinia, R.; Avan, A.; Ahmadian, M.; Nia, S.N.; Ranjbar, M.; Sharifi, M.; Goli, M.; Piroozmand, A.; Nourmohammadi, E.; Manian, M.; et al. Current Status and Perspectives Regarding LNA-Anti-miR Oligonucleotides and microRNA miR-21 Inhibitors as a Potential Therapeutic Option in Treatment of Colorectal Cancer. J. Cell. Biochem. 2017, 118, 4129-4140. [CrossRef] [PubMed]

207. Osaki, M.; Takeshita, F.; Sugimoto, Y.; Kosaka, N.; Yamamoto, Y.; Yoshioka, Y.; Kobayashi, E.; Yamada, T.; Kawai, A.; Inoue, T.; et al. MicroRNA-143 regulates human osteosarcoma metastasis by regulating matrix metalloprotease-13 expression. Mol. Ther. 2011, 19, 1123-1130. [CrossRef]

208. Wang, R.; Sun, Y.; Yu, W.; Yan, Y.; Qiao, M.; Jiang, R.; Guan, W.; Wang, L. Downregulation of miRNA-214 in cancer-associated fibroblasts contributes to migration and invasion of gastric cancer cells through targeting FGF9 and inducing EMT. J. Exp. Clin. Cancer Res. 2019, 38, 20. [CrossRef]

209. Mollaei, H.; Safaralizadeh, R.; Rostami, Z. MicroRNA replacement therapy in cancer. J. Cell. Physiol. 2019, 234, 12369-12384. [CrossRef]

210. Weiler, J.; Hunziker, J.; Hall, J. Anti-miRNA oligonucleotides (AMOs): Ammunition to target miRNAs implicated in human disease? Gene Ther. 2006, 13, 496-502. [CrossRef]

211. Stenvang, J.; Petri, A.; Lindow, M.; Obad, S.; Kauppinen, S. Inhibition of microRNA function by antimiR oligonucleotides. Silence 2012, 3, 1. [CrossRef]

212. Yu, B.; Chen, X. Analysis of miRNA Modifications. Methods Mol. Biol. 2010, 592, 137-148. [CrossRef]

213. Lima, J.F.; Cerqueira, L.; Figueiredo, C.; Oliveira, C.; Azevedo, N.F. Anti-miRNA oligonucleotides: A comprehensive guide for design. RNA Biol. 2018, 15, 338-352. [CrossRef]

214. Lennox, K.A.; Owczarzy, R.; Thomas, D.M.; Walder, J.A.; Behlke, M.A. Improved performance of anti-miRNA oligonucleotides using a novel non-nucleotide modifier. Mol. Ther. Nucleic Acids 2013, 2, e117. [CrossRef] [PubMed]

215. Chakraborty, C.; Wen, Z.-H.; Agoramoorthy, G.; Lin, C.-S. Therapeutic microRNA Delivery Strategies with Special Emphasis on Cancer Therapy and Tumorigenesis: Current Trends and Future Challenges. Curr. Drug Metab. 2016, 17, 469-477. [CrossRef] [PubMed]

216. PRISM: Efficacy and Safety of Cobomarsen (MRG-106) in Subjects With Mycosis Fungoides Who Have Completed the SOLAR Study-Full Text View_ClinicalTrials.gov. Available online: https:/ / clinicaltrials.gov/ct2/show / NCT03837457?term=miragen\& draw $=2 \&$ rank $=1$ (accessed on 16 April 2020).

217. SOLAR: Efficacy and Safety of Cobomarsen (MRG-106) vs. Active Comparator in Subjects With Mycosis Fungoides-Full Text View-ClinicalTrials.gov. Available online: https://clinicaltrials.gov/ct2/show/NCT03713320 (accessed on 16 April 2020).

218. Seto, A.G.; Beatty, X.; Lynch, J.M.; Hermreck, M.; Tetzlaff, M.; Duvic, M.; Jackson, A.L. Cobomarsen, an oligonucleotide inhibitor of miR-155, co-ordinately regulates multiple survival pathways to reduce cellular proliferation and survival in cutaneous T-cell lymphoma. Br. J. Haematol. 2018, 183, 428-444. [CrossRef] [PubMed]

219. Bader, A.G.; Brown, D.; Winkler, M. The promise of microRNA replacement therapy. Cancer Res. 2010, 70, 7027-7030. [CrossRef] [PubMed]

220. Yang, N. An overview of viral and nonviral delivery systems for microRNA. Int. J. Pharm. Investig. 2015, 5, 179-181. [CrossRef]

221. Nayak, S.; Herzog, R.W. Progress and prospects: Immune responses to viral vectors. Gene Ther. 2010, 17, 295-304. [CrossRef]

222. Schade, A.; Delyagina, E.; Scharfenberg, D.; Skorska, A.; Lux, C.; David, R.; Steinhoff, G. Innovative strategy for microRNA delivery in human mesenchymal stem cells via magnetic nanoparticles. Int. J. Mol. Sci. 2013, 14, 10710-10726. [CrossRef]

223. Cao, M.; Deng, X.; Su, S.; Zhang, F.; Xiao, X.; Hu, Q.; Fu, Y.; Yang, B.B.; Wu, Y.; Sheng, W.; et al. Protamine sulfate-nanodiamond hybrid nanoparticles as a vector for MiR-203 restoration in esophageal carcinoma cells. Nanoscale 2013, 5, 12120-12125. [CrossRef] 
224. Tivnan, A.; Orr, W.S.; Gubala, V.; Nooney, R.; Williams, D.E.; McDonagh, C.; Prenter, S.; Harvey, H.; Domingo-Fernández, R.; Bray, I.M.; et al. Inhibition of neuroblastoma tumor growth by targeted delivery of microRNA-34a using anti-disialoganglioside GD2 coated nanoparticles. PLoS ONE 2012, 7, e38129. [CrossRef]

225. O'Neill, C.P.; Dwyer, R.M. Nanoparticle-Based Delivery of Tumor Suppressor microRNA for Cancer Therapy. Cells 2020, 9 , 521. [CrossRef]

226. Ganju, A.; Khan, S.; Hafeez, B.B.; Behrman, S.W.; Yallapu, M.M.; Chauhan, S.C.; Jaggi, M. miRNA nanotherapeutics for cancer. Drug Discov. Today 2017, 22, 424-432. [CrossRef] [PubMed]

227. Hao, Z.; Fan, W.; Hao, J.; Wu, X.; Zeng, G.Q.; Zhang, L.J.; Nie, S.F.; Wang, X.D. Efficient delivery of micro RNA to bone-metastatic prostate tumors by using aptamer-conjugated atelocollagen in vitro and in vivo. Drug Deliv. 2016, 23, 874-881. [CrossRef] [PubMed]

228. Ishihara, Y.; Tsuno, S.; Kuwamoto, S.; Yamashita, T.; Endo, Y.; Miura, K.; Miura, Y.; Sato, T.; Hasegawa, J.; Miura, N. Tumorsuppressive effects of atelocollagen-conjugated hsa-miR-520d-5p on un-differentiated cancer cells in a mouse xenograft model. BMC Cancer 2016, 16, 415. [CrossRef]

229. Wang, H.; Liu, S.; Jia, L.; Chu, F.; Zhou, Y.; He, Z.; Guo, M.; Chen, C.; Xu, L. Nanostructured lipid carriers for MicroRNA delivery in tumor gene therapy. Cancer Cell Int. 2018, 18. [CrossRef] [PubMed]

230. Vickers, K.C.; Remaley, A.T. Lipid-based carriers of microRNAs and intercellular communication. Curr. Opin. Lipidol. 2012, 23, 91-97. [CrossRef]

231. Bonneau, E.; Neveu, B.; Kostantin, E.; Tsongalis, G.J.; De Guire, V. How close are miRNAs from clinical practice? A perspective on the diagnostic and therapeutic market. Electron. J. Int. Fed. Clin. Chem. Lab. Med. 2019, 30, 114-127.

232. Baumann, V.; Winkler, J. MiRNA-based therapies: Strategies and delivery platforms for oligonucleotide and non-oligonucleotide agents. Future Med. Chem. 2014, 6, 1967-1984. [CrossRef]

233. Hanna, J.; Hossain, G.S.; Kocerha, J. The Potential for microRNA Therapeutics and Clinical Research. Front. Genet. 2019, 10, 478. [CrossRef] 